DEMOGRAPHIC RESEARCH

VOLUME 37, ARTICLE 8, PAGES 189-228

PUBLISHED 27 JULY 2017

http://www.demographic-research.org/Volumes/Vol37/8/

DOI: 10.4054/DemRes.2017.37.8

Research Article

Cross-national differences in women's repartnering behaviour in Europe: The role of individual demographic characteristics

\title{
Paulina Gałęzewska
}

\section{Brienna Perelli-Harris}

\section{Ann Berrington}

This publication is part of the Special Collection on "Separation, Divorce, Repartnering, and Remarriage around the World," organized by Guest Editors Benoît Laplante and Andrew Cherlin.

(C) 2017 Gatęzewska, Perelli-Harris \& Berrington.

This open-access work is published under the terms of the Creative Commons Attribution NonCommercial License 2.0 Germany, which permits use, reproduction \& distribution in any medium for non-commercial purposes, provided the original author(s) and source are given credit. See http://creativecommons.org/licenses/by-nc/2.0/de/ 


\section{Contents}

1 Introduction 190

2 Theoretical framework 193

2.1 Demographic characteristics affecting women's repartnering 193

2.2 Cross-national variation in repartnering behaviour 196

3 Data and analytical approach 199

$4 \quad$ Results 201

4.1 Descriptive statistics 201

4.1.1 Life table estimates of repartnering 201

4.1.2 Demographic characteristics at time of separation 203

4.2 Single-country regression models 208

4.3 Pooled regression model 212

$\begin{array}{lll}5 & \text { Discussion } & 215\end{array}$

6 Acknowledgements 218

References 


\title{
Cross-national differences in women's repartnering behaviour in Europe: The role of individual demographic characteristics
}

\author{
Paulina Gałęzewska ${ }^{1}$ \\ Brienna Perelli-Harris ${ }^{2}$ \\ Ann Berrington ${ }^{2}$
}

\begin{abstract}
BACKGROUND

With rising union instability across Europe, more individuals now re-enter the partner market and eventually repartner. The increase in cohabitation may also be influencing repartnering behaviour. While several studies examine individual-level characteristics related to repartnering, few take a broader view and compare repartnering levels or explore how demographic characteristics associated with repartnering differ across Europe.
\end{abstract}

\section{OBJECTIVE}

We describe levels of repartnering and the characteristics of those exposed to repartnering in 11 European countries. We then examine whether the relationship between women's demographic characteristics at union dissolution and repartnering are similar or different across countries. Given the recent increase in cohabitation, we pay particular attention to prior cohabitation and marriage, but we also compare age at first union dissolution, first union duration, and presence of children.

\section{METHODS}

Using the Harmonized Histories database, we apply discrete-time hazard models separately by country and to pooled cross-national data.

\section{RESULTS}

Despite large differences in levels of repartnering, in most countries we find similar associations between demographic characteristics and repartnering. First union type did not matter after controlling for age and children, except in France, where those who previously cohabited had significantly lower risks of repartnering. Age at union

\footnotetext{
${ }^{1}$ University of Southampton, United Kingdom. E-Mail: paulina.galezewska@gmail.com.

${ }^{2}$ University of Southampton, United Kingdom.
} 
dissolution and presence of children are negatively associated with repartnering in almost all countries.

\section{CONCLUSION}

Although cohabitation has increased everywhere, prior experience of a coresidential partnership outside of formal marriage makes little difference to repartnering behaviour after controls (except in France). However, regardless of country, older women and/or mothers are less likely to form second unions.

\section{Introduction}

Since the 1960s divorce rates have risen in nearly every European country and in the United States (Raley and Bumpass 2003; Kalmijn 2007; Sobotka and Toulemon 2008; Spijker 2012; Kennedy and Ruggles 2014). In addition, many countries, especially in Northern and Western Europe, have experienced an increase in cohabiting unions, often a testing ground for relationships that end in union dissolution (Kiernan 2004; Beaujouan and Ní Bhrolcháin 2011; Perelli-Harris et al. 2017). The increased instability of both marital and cohabiting partnerships has led to a rise in the levels of repartnering in nearly all European countries (Gałęzewska 2016). However, the variation in partnership dynamics across the continent is very large. For example, among all women born in 1955-1964, the estimated percentage of those who had ever experienced second union formation by the early 2000 s ranged from $2 \%-8 \%$ in Southern and most Eastern European countries to $17 \%-21 \%$ in Estonia and Russia and around $30 \%$ in Norway (Gałęzewska 2016).

Variation in cohabitation, separation, and repartnering throughout Europe indicates that the processes of family formation are context-specific. Therefore we would also expect the determinants of repartnering to differ cross-nationally. Although a growing body of literature has investigated the determinants of second union formation in various European countries (Lampard and Peggs 1999; de Graaf and Kalmijn 2003; Poortman 2007; Meggiolaro and Ongaro 2008; Skew, Evans, and Gray 2009; Jaschinski 2011; Beaujouan 2012; Ivanova, Kalmijn, and Uunk 2013; Vanassche et al. 2015; Murinkó and Szalma 2016), most studies have focused on a single country. To our knowledge, only a few micro-level studies have examined repartnering in a crossnational perspective: for example, comparing the United Kingdom and Australia (Skew, Evans, and Gray 2009); Norway, France, Germany, Romania, and Russia (Ivanova, Kalmijn, and Uunk 2013); and France, Hungary, and Norway (Murinkó and Szalma 2016). This paper extends this work by examining whether the factors associated with repartnering are similar or different in 11 European countries representing a variety of 
family regimes and union formation patterns, including countries like Poland and Italy, where the increase in divorce is more recent (Hajnal 1965, 1982). Although our country selection is somewhat driven by data availability, the countries represent a range of regions and welfare regimes: Scandinavian (Norway and Sweden); liberal (United Kingdom); continental (Belgium, France, and the Netherlands); Mediterranean (Italy); and post-Socialist (Estonia, Hungary, Poland, and Russia). Differing institutional, policy, and legal contexts may influence whether marriage or childbearing in the first partnership might relate to the speed of repartnering in some countries but not others.

In this study we pay particular attention to the role of cohabitation in repartnering. The majority of previous research studying repartnering in Europe and North America has predominantly focused on marital divorce (e.g., Bumpass, Sweet, and Martin 1990; Wu 1994; Sweeney 1997, 2002; Lampard and Peggs 1999; de Graaf and Kalmijn 2003; Meggiolaro and Ongaro 2008; Jaschinski 2011; Ivanova, Kalmijn, and Uunk 2013; Theunis, Pasteels, and van Bavel 2015; Vanassche et al. 2015). Less is known about repartnering after separation from cohabitation (Wu and Schimmele 2005; Poortman 2007; Skew, Evans, and Gray 2009). This is a gap in our understanding, since the population of women exposed to repartnering is increasingly composed of women who experienced nonmarital first union dissolution (Gałęzewska 2016). Moreover, studies have demonstrated that the cohabiting and the married differ, for instance, in their family and gender attitudes (Lesthaeghe 2010), fertility behaviour (Kiernan 2001; Perelli-Harris 2014), and subjective well-being (Soons and Kalmijn 2009), which in turn may have implications for repartnering behaviour. On the other hand, cohabitation and marriage may be very similar: For example, in Scandinavian countries, cohabitation is now the normative setting for childbearing. Focus group research from Norway suggests that cohabitation and marriage are indistinguishable, especially at the time of childbearing, although some still marry for romantic reasons (Lappegård and Noack 2015). While the meaning and practice of cohabitation is very heterogeneous across countries (Perelli-Harris et al. 2014), this study provides new insights into these crossnational differences by examining whether marriage or cohabitation at first union matters for second union formation.

We also examine the association between women's age and children at first union dissolution, which could impact a woman's need, opportunity, and attractiveness in the repartnering process (de Graaf and Kalmijn 2003; Ivanova, Kalmijn, and Uunk 2013; Theunis, Pasteels, and van Bavel 2015; Vanassche et al. 2015; Murinkó and Szalma 2016). Individual demographic characteristics such as age and previous fertility have been seen to influence women's chances and constraints in the repartnering market (Lampard and Peggs 1999; de Graaf and Kalmijn 2003; Wu and Schimmele 2005; Poortman 2007; Meggiolaro and Ongaro 2008; Skew, Evans, and Gray 2009; Beaujouan 2012; Ivanova, Kalmijn, and Uunk 2013; Vanassche et al. 2015). Yet these 
associations may differ across countries depending on, for example, women's economic independence (need), the pool of partners willing to marry divorced or separated women (opportunity), and the stigma of divorced women (attractiveness) (de Graaf and Kalmijn 2003; Ivanova, Kalmijn, and Uunk 2013; Vanassche et al. 2015; Murinkó and Szalma 2016). The effect of children on a woman's attractiveness may vary across countries; for example, children may be a greater obstacle to repartnering in countries where divorce is rare and social norms about fatherhood are more conservative, while in countries where stepfamilies are common, men may not be as reluctant to take on the role of stepfather. In addition, policies such as childcare provision and flexible working arrangements may influence the effect of children on second union formation (de Graaf and Kalmijn 2003).

Although shared custody of dependent children has recently increased in some countries, including Belgium, the Netherlands, and Sweden (Spruijt and Duindam 2009; Sodermans, Matthijs, and Vanassche 2013; Vanassche et al. 2015), our analyses focus on women's repartnering, as women traditionally obtain legal custody over minor children after separation (Beaumont and Manson 2014). Economic deterioration following separation is generally greater for women and their children than for men (for review see Aassve et al. 2007 and Andreß et al. 2006). Additionally, data constraints do not permit examination of men's repartnering behaviour in all the studied countries. Furthermore, data constraints mean that we define repartnering as forming a new coresidential partnership. Some people form living-apart-together relationships after partnership dissolution, sometimes in response to policies that may deter women from repartnering, e.g., to maintain lone parent benefits, or due to a preference to remain independent (Regnier-Loilier, Beaujouan, and Villeneuve-Gokalp 2009). Thus, in interpreting our findings we should be aware that some women who do not repartner may nevertheless be in a stable, committed relationship.

This paper first discusses why different demographic characteristics may be associated with repartnering, and how the associations may differ across countries. Next, we examine at the aggregate level the diversity in the overall level and pace of repartnering across Europe, which is commonly overlooked in previous work focusing solely on individual-level determinants. We present basic descriptive statistics of crossnational differences in levels of repartnering and how they differ according to key demographic characteristics. Then, using multiple regression analyses of individual data, we test whether the effects of women's age, the presence of children at union dissolution, and the type and duration of first union on the likelihood of repartnering are universal across our studied countries. Taken together, these analyses help us understand not only whether the factors associated with the formation of second coresidential unions differs across countries, but also the extent to which a new family form - cohabitation - makes a difference to subsequent family formation. 


\section{Theoretical framework}

\subsection{Demographic characteristics affecting women's repartnering behaviour}

First union type. The experience of living with a partner outside of formal marriage can impact an individual's attitudes towards marriage and family formation (Cunningham and Thornton 2005) and may make a fundamental difference to women's repartnering behaviour, yet most of the existing literature has focused on repartnering after divorce (Bumpass, Sweet, and Martin 1990; Wu 1994; Sweeney 1997; Lampard and Peggs 1999; Sweeney 2002; de Graaf and Kalmijn 2003; Meggiolaro and Ongaro 2008; Ivanova, Kalmijn, and Uunk 2013; Vanassche et al. 2015), and few studies have distinguished between the repartnering of previously cohabiting and divorced women (Blanc 1987; Poortman 2007; Skew, Evans, and Gray 2009; Wu and Schimmele 2005). Some evidence has indicated that cohabitors and divorcees are likely to differ in their chances and timing of repartnering (Skew, Evans, and Gray 2009; Wu and Schimmele 2005). Studies providing life-table estimates of repartnering by first union type have shown that previously cohabiting women form a second coresidential union at a faster pace than divorced women (Blanc 1987; Skew, Evans, and Gray 2009). Results from multivariate analyses are less conclusive, depending on the definition of first union type and the studied event, i.e., repartnering in general, or entry into either cohabiting or marital second union (Skew, Evans, and Gray 2009; Poortman 2007). For example, in the Netherlands previously cohabiting women have higher risks of repartnering than divorcees (Poortman 2007), while no significant effect of first union type on repartnering has been documented for separated individuals in the United Kingdom (Skew, Evans, and Gray 2009).

Cohabitation is inherently a heterogeneous relationship form, ranging from those who have just started dating to those who have lived together in a permanent relationship for many years (Perelli-Harris et al. 2014). Nonetheless, on average cohabiting unions tend to be less stable than marital unions (Heuveline, Timberlake, and Furstenberg, Jr. 2003; Beaujouan and Ní Bhrolcháin 2011; Gałęzewska 2016). Cohabitors who dissolve their unions tend to be younger than married couples who divorce, because many cohabitors either marry their partner within a few years or dissolve their unions (Beaujouan and Ní Bhrolcháin 2011). This instability, especially at younger ages, results in increased exposure to repartnering and possibly a quicker pace of repartnering. In addition, cohabitors tend to have fewer or no children, which may make them more attractive to new partners following dissolution. Finally, cohabitors often have less traditional family attitudes, lower levels of religiosity, and a greater orientation to individualization (Surkyn and Lesthaeghe 2004; Lesthaeghe 2010), which may make multiple relationships acceptable. 
Repartnering after divorce may take longer. Divorcees may need a longer recovery time than individuals whose cohabiting union has dissolved, since the end of a marriage means the failure of fulfilling a formal commitment (Blanc 1987) and divorce itself can be a strenuous and expensive procedure (Amato 2000). In addition, individuals who experience marital union dissolution may face a stigma that makes them less attractive to a potential partner (Ivanova, Kalmijn, and Uunk 2013; Meggiolaro and Ongaro 2008). Divorced individuals are also often older and have children, which might make them less attractive in the repartnering market. Finally, given that marital partnerships are often perceived to be more committed than cohabiting relationships (Perelli-Harris et al. 2014), re-entering a partnership after a painful break-up may be more difficult for those who have divorced.

First union duration. The increasing length of a first union may facilitate or hinder repartnering (Bumpass, Sweet, and Martin 1990). On the one hand, women in long first unions may be more marriage-oriented or may have developed skills relating to home production that are of value in a new marriage (ibid.). Furthermore, women in long relationships have spent most of their adult lives with a partner, which may impede their adjustment to single life and encourage them to re-marry. The financial benefits of partnership tends to be positively associated with the length of union (Becker, Landes, and Michael 1977), possibly spurring those in longer unions to repartner more quickly in order to benefit from a new union in a similar way (Wu and Balakrishnan 1994). Longer first unions may also be positively assessed as they imply the ability to commit long-term (Poortman 2007). On the other hand, women whose first union was very long may lack experience in searching for a partner (Koo, Suchindran, and Griffith 1984), or may have more difficulty separating from their first partner and disentangling themselves from joint commitments such as a shared family home, resulting in slower repartnering.

Prior studies have found a positive effect of union duration on repartnering in the Netherlands (Poortman 2007). A Dutch woman's chance of entering a new union increases if her first partnership lasted three years or longer. De Graaf and Kalmijn (2003) have also reported a positive effect of first marriage duration on women's repartnering for the Netherlands, as have Ivanova, Kalmijn, and Uunk (2013) for Russian women. However, union duration appears to have no effect on women's repartnering in the United Kingdom (Skew, Evans, and Gray 2009) or in France, Germany, Norway, and Romania (Ivanova, Kalmijn, and Uunk 2013).

Women's age at first union dissolution. Age at first union dissolution may be one of the most important predictors of repartnering (Beaujouan 2012; Lampard and Peggs 1999; Meggiolaro and Ongaro 2008; Poortman 2007; Skew, Evans, and Gray 2009; Wu and Schimmele 2005). With women's increasing age, the pool of potential partners decreases because men tend to form unions with younger women (Ní Bhrolcháin 1992; 
England and McClintock 2009). Also, women's attractiveness to a potential partner may decrease with age because of declining physical attractiveness and health status (Skew, Evans, and Gray 2009), or because older women may be less willing or unable, due to biological limits on fertility, to have (further) children (Beaujouan 2012). Finally, Skew and colleagues (2009) argue that age may reveal some generational attitudes towards repartnering, as people who are older at union dissolution may have a more traditional view of union formation and therefore be more reluctant to repartner. In Europe, age at union dissolution has a negative effect on women's repartnering; for example, in France (Beaujouan 2012), Flanders in Belgium (Vanassche et al. 2015; Theunis, Pasteels, and Van Bavel 2015), Germany (Jaschinski 2011), Italy (Meggiolaro and Ongaro 2008), the Netherlands (Poortman 2007), and the United Kingdom (Skew, Evans, and Gray 2009; Lampart and Peggs 1999).

Presence of children at union dissolution. Having dependent children in a household is generally viewed as an obstacle to women's repartnering (Sweeney 1997; Lampard and Peggs 1999; Poortman 2007; Meggiolaro and Ongaro 2008; Skew, Evans, and Gray 2009; Beaujouan 2012; Ivanova, Kalmijn, and Uunk 2013; Theunis, Pasteels, and Van Bavel 2015; Vanassche et al. 2015). The presence of children at union dissolution may affect women's repartnering in various ways. First, it may affect women's attractiveness in the partner market (de Graaf and Kalmijn 2003; Ivanova, Kalmijn, and Uunk 2013; Goldscheider and Kaufman 2006; Vanassche et al. 2015), as a potential partner has to take into account the direct financial costs of raising a woman's children and face the challenges associated with the complexity of stepfamilies (Stewart, Manning, and Smock 2003; Stewart 2005; Allan, Crow, and Hawker 2011). Second, dependent children are also likely to restrict women's meeting opportunities as they increase the cost of time women spend searching for a new partner (de Graaf and Kalmijn 2003; Ivanova, Kalmijn, and Uunk 2013). Given that having children is usually associated with a stronger emotional investment and a long-term commitment to a partner, mothers may perceive union dissolution as more harmful than their childless counterparts and develop a more cautious attitude towards entering a new union (Lampard and Peggs 1999; Poortman 2007). Also, as children are often prioritized in terms of time and affection, some mothers may not be willing to form a new relationship when children are young or if the children do not accept a potential step-parent (Lampard and Peggs 1999). However, since mothers experience more adverse economic consequences of union dissolution than their childless counterparts (Amato 2000), having children may increase women's need to repartner in order to improve the household's financial situation (de Graaf and Kalmijn 2003; Ivanova, Kalmijn, and Uunk 2013). Finally, separated childless women with a strong desire for children may want to quickly form a second union to achieve their childbearing intentions (Beaujouan and Solaz 2013). 


\subsection{Cross-national variation in repartnering behaviour}

European countries differ in the demographic, socioeconomic, institutional, and cultural context in which repartnering is embedded (Hajnal 1965). Contextual factors are important because they may influence the interplay between individual-level characteristics and repartnering behaviour, resulting in different associations across countries (Billari 2015).

First, it is important to note that the rate of diffusion of new family behaviours has differed dramatically across the continent and these differences may influence interrelationships between demographic characteristics and repartnering. Scandinavian countries such as Norway and Sweden have been forerunners in adopting new behaviours such as late entry into marriage, low marriage rates, and high union instability (Sobotka and Toulemon 2008). In Norway cohabitation is widespread and viewed as a normative stage in the family formation process, including as a setting for childbearing (Syltevik 2010; Lappegård and Noack 2015). In addition, repartnering and multi-partner fertility are relatively common and accepted (Thomson et al. 2014). In Western European countries (represented in our study by Belgium, France, the Netherlands, and the United Kingdom), cohabitation prior to marriage is normative, and childbearing within cohabitation is widely practiced (Perelli-Harris et al. 2012). Divorce rates are also very high; however, they vary considerably across Western Europe. For example, the total divorce rate (TDR) in 2005 ranges from 0.37 in the Netherlands to 0.58 in Belgium (Spijker 2012).

In Southern and Eastern Europe, marriage remains the dominant family arrangement. In Italy cohabitation has increased recently, but only to about $12 \%$ of couples in 2013 (Pirani and Vignoli 2016). Divorce in Italy was introduced comparatively late, in 1970, and the divorce rate is still one of the lowest in Europe (Spijker 2012). Eastern European countries (represented here by Hungary, Poland, Russia, and Estonia) generally have strong marriage norms, low levels of cohabitation, and relatively high divorce rates (Perelli-Harris et al. 2017), but some countries exhibit important differences. In Poland, traditional values reflect the influence of the Catholic Church and result in a low prevalence of cohabitation (Mynarska and Bernardi 2007), and low divorce rates (Spijker 2012). By contrast, its high level of cohabitation and moderate divorce rates make Estonia more similar to Scandinavian countries than to the rest of Eastern Europe (Katus et al. 2007).

Second, economic conditions, legal policies, and welfare state regulations influence women's need to repartner (de Graaf and Kalmijn 2003; Ivanova, Kalmijn, and Uunk 2013; Vanassche et al. 2015). Repartnering may serve as an effective strategy to offset declines in household income following separation (Ozawa and Yoon 2002; Dewilde and Uunk 2008; Jansen, Mortelmans, and Snoeckx 2009; de Regt, Mortelmans, and Marynissen 2012). However, comparative evidence has suggested that 
the financial consequences of separation vary across Europe (Dewilde 2002; Uunk 2004; Andreß et al. 2006; Aassve et al. 2007). Welfare state arrangements, particularly policies to support lone parents and labour market regulations enhancing mothers' employment, may mitigate the adverse consequences of union dissolution (Dewilde 2002; Uunk 2004; Andreß et al. 2006). Attention has also been paid to the extent and the character of welfare transfers, i.e., universal (e.g., Sweden) or means-tested (e.g., the United Kingdom), showing that financial deterioration after union dissolution is smaller in countries with more generous benefits for lone mothers (ibid.). Furthermore, policies targeting mothers' full-time employment, in particular the availability and acceptability of public childcare, are likely to improve women's economic situation (Raeymaeckers et al. 2008; van Damme, Kalmijn, and Uunk 2009). At the same time, welfare benefits, public childcare provision, and easy access to paid full-time employment, i.e., arrangements aimed at increasing women's economic independence, are also likely to reduce women's incentive to repartner for financial reasons (de Graaf and Kalmijn 2003; Dewilde and Uunk 2004). On the other hand, increased labour force participation increases the chance of meeting a partner through the workplace (de Graaf and Kalmijn 2003). Repartnering may also depend on country-specific laws governing divorce and nonmarital union dissolution. Although divorce has been legal in the majority of Western societies since the 1950s, countries differ as to when major reforms introducing non-fault, mutual-consent, and unilateral divorce were implemented (Perelli-Harris et al. 2017). Different types of divorce legislation imply different administrative practices, i.e., the cost and length of the procedure (including the separation period) vary, which suggests varying direct costs of union dissolution across countries. Countries differ also in the regulation of the financial aftermath of divorce, such as child support, spouse alimony, and custodial arrangements, and whether cohabiting couples have rights or responsibilities upon union dissolution (Sánchez Gassen and Perelli-Harris 2015; Vanassche et al. 2015).

Third, divorced and separated women may differ across countries in their attractiveness in the repartnering market (de Graaf and Kalmijn 2003; Ivanova, Kalmijn, and Uunk 2013; Vanassche et al. 2015). Societal attitudes towards divorce and stepfamily may affect second union formation (Goldscheider and Kaufman 2006; Goldscheider, Kaufman, and Sassler 2009). In countries where divorce is uncommon, especially in more religious countries such as Italy, divorcees may be stigmatized, making them less attractive as a potential partner (Gelissen 2003; Liefbroer and Fokkema 2008; Meggiolaro and Ongaro 2008; Ivanova, Kalmijn, and Uunk 2013). Nonetheless, although the acceptance of divorce has increased slightly over time in many European countries (Liefbroer and Fokkema 2008), in some countries negative attitudes towards divorce have prevailed when children are involved (Rijken and Liefbroer 2012). Persistent high divorce rates over a longer period of time may also 
have indirect effects on repartnering through the intergenerational transmission of attitudes: Some studies have suggested that individuals who experience nontraditional family forms in childhood are more likely to marry someone previously married or with children (Bernhardt and Goldscheider 2002; Goldscheider and Kaufman 2006; Goldscheider and Sassler 2006).

Finally, repartnering chances depend on the opportunity to repartner, or the availability (supply) of potential partners (de Graaf and Kalmijn 2003). In countries where union dissolution is very common, previously married or cohabiting men constitute a significant share of the pool of potential partners; for example, in Norway, the United Kingdom, Estonia, France, and Russia compared to Italy and Poland. Moreover, the structure of the partner market regarding men's individual characteristics, for instance, age, previous union and fertility history, and socioeconomic status, may impact women's opportunities to find a partner (Ní Bhrolcháin and Sigle-Rushton 2005; Shafer and James 2013; Theunis, Pasteels, and Van Bavel 2015). Since women are disadvantaged in the partner market due to unbalanced sex ratios at higher ages and men's preference for younger women (England and McClintock 2009), repartnering rates should be higher in countries where women's mean age at union dissolution is relatively young. The partner market structure in terms of males' partnership history is important, as divorced men may have more favourable attitudes towards and be more likely to enter into a union with divorcees or mothers (Bernhardt and Goldscheider 2002; Stewart, Manning, and Smock 2003; Goldscheider and Kaufman 2006; Goldscheider, Kaufman, and Sassler 2009; Vanassche et al. 2015).

Taken together, differences in women's age and presence of children at union dissolution as well as the type and duration of first partnership may explain why some women are more likely to repartner than others. At the same time, cross-national differences in the rate of diffusion of new family behaviours, in socioeconomic and institutional arrangements as well as in the opportunities and the attractiveness of the separated women in the repartnering market, may explain the variation in repartnering levels across Europe. Given the complexity of the interplay between women's demographic characteristics and contextual factors we refrain from formulating country-specific repartnering hypotheses. However, due to the general acceptability of cohabitation and divorce across Northern and Western Europe we might expect few differences in repartnering behaviour according to first partnership type, age at dissolution, and/or parental status. For Southern and Eastern European countries, on the other hand, we hypothesise differences in the association between first union type and repartnering behaviour, resulting from the generally prevailing strong marriage norms. 


\section{Data and analytical approach}

Harmonized Histories. The data comes from the Harmonized Histories, a cross-national dataset which contains harmonized fertility and partnership histories collected in the British Household Panel Survey (2005-2006), the Dutch Fertility and Family Survey (2003), and Generations and Gender Surveys in Belgium (2008-2010), Estonia (20042005), France (2005), Hungary (2004-2005), Italy (2003), Norway (2007-2008), Poland (2010-2011), Russia (2004), and Sweden (2012-2013) (for more information, see www.nonmarital.org). Our analytical sample consists of women born in 1950-1969, who entered a first union before exact age 40 which subsequently dissolved (Table 1). To ensure comparability across countries, despite differences in survey interview year, the analysis is restricted to the calendar period before 2005. Consequently, repartnering behaviours of women aged 35 to 55 at the time of the survey are examined. Sample size varies from 296 in Belgium to 1,037 in Norway and comprises 7,332 women in total, of which 3,841 had formed a second coresidential union within the ten years after first union dissolution. If available, survey weights are applied in order to show nationally representative results.

Analytical approach. First we provide insights into the repartnering dynamics of women born 1950-1969 across Europe using life table estimates, and examine how the population at risk of repartnering varies in terms of individual-level demographic characteristics - women's age at first union dissolution, presence of children (i.e., motherhood status), and the type and duration of the dissolved first union - across European countries. Women who married their first partner directly as well as those who married after a period of premarital cohabitation are assigned to the marriage category. Women living in nonmarital coresiding unions at the time of union dissolution constitute the category 'cohabitation.'

Discrete-time logistic hazard models (Allison 1982) are used to estimate the logodds that an individual experiences repartnering in month $t$ given that this event has not occurred yet. The model is defined as follows:

$$
\log \left(\frac{P_{i t}}{1-P_{i t}}\right)=\propto_{t}+\beta_{1} x_{i t 1}+\cdots+\beta_{k} x_{i t k}
$$

We present our results using exponentials of the regression coefficients $\beta$, i.e., odds ratios. Exposure to repartnering begins with the month of separation or divorce, depending on which comes first. ${ }^{3}$ The event - repartnering - occurs the month the woman enters a second coresidential union. Observations have been censored when

${ }^{3}$ For simplicity, we refer to women who dissolved their marital first union as 'divorcees' even though the legal divorce may have occurred later, after separation. 
women have not found a new partner within the ten years after first union dissolution, or at the time of the survey.

\section{Table 1: Description of the sample}

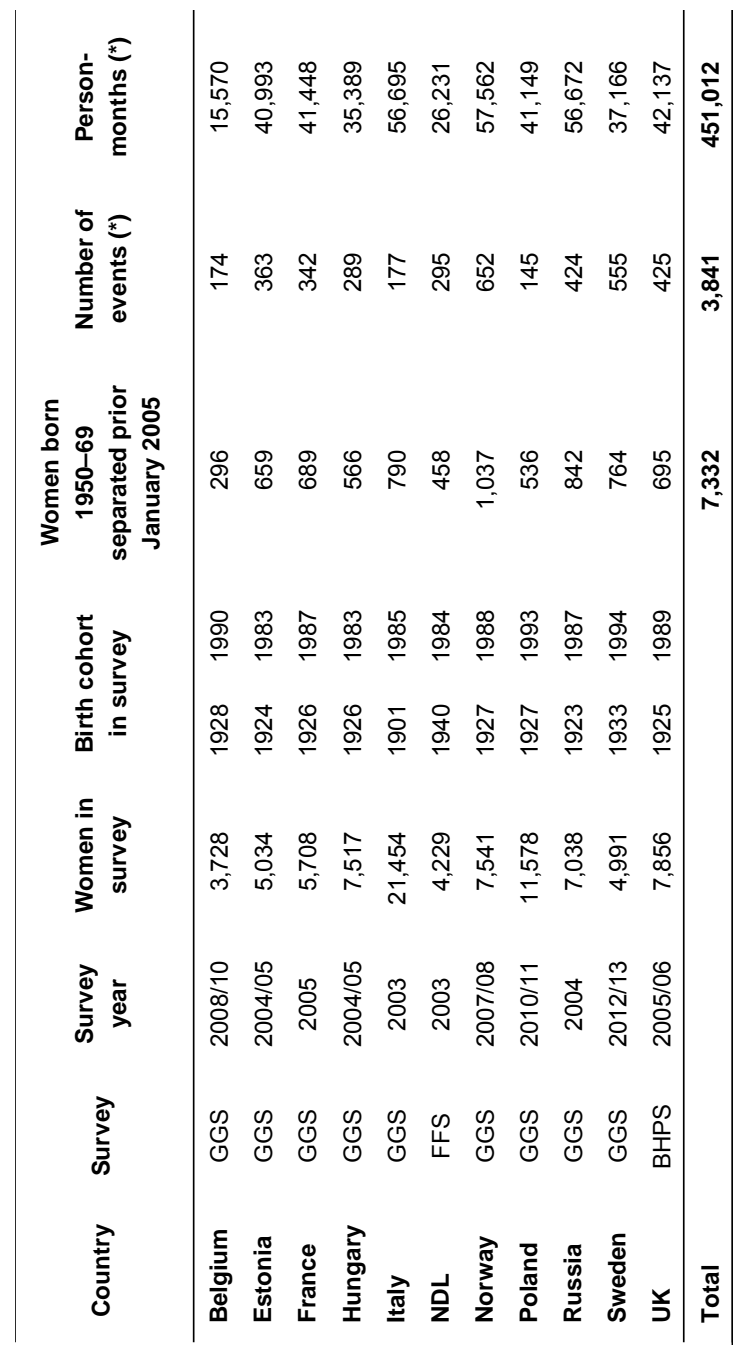

Note: $\left({ }^{*}\right)$ Female birth cohort 1950-1969, within ten years since separation, women's experiences are censored at January 2005 (2003 in Italy and the Netherlands) to allow comparability across countries. 
We proceed in two stages. First, we take each of the 11 countries individually and examine the association between the likelihood of repartnering and our set of individual-level characteristics: first partnership type (cohabiting vs. marriage (ref.)), duration of first union at dissolution (numeric), women's age at first union dissolution (numeric), the presence of children at dissolution (yes vs. no (ref.)), and birth cohort (1950-1959 vs. 1960-1969 (ref.)). Subsequently, we use a pooled model and include interaction terms between country and all explanatory variables to test whether the effect of the woman's demographic characteristics on repartnering differs between countries (as previously done in Liefbroer and Dourleijn (2006)). ${ }^{4}$ We choose France as a reference category due to its moderate level of union dissolution and cohabitation. ${ }^{5}$ To facilitate interpretation, results are presented in form of monthly predicted probabilities of repartnering by first union type, for childless women. Additional information on statistically significant effects is also provided.

\section{Results}

\subsection{Descriptive statistics}

\subsubsection{Life table estimates of repartnering}

Of substantive interest is both the overall level and the pace of repartnering (Beaujouan 2012). While previous research has focused on the individual-level covariates associated with the chance of repartnering in a single country or a few countries, this study is the first to provide comparative data showing the significant range in levels of repartnering. Life table estimates of the cumulative percentages of women born in 1950-1969 in each country, who repartnered within ten years after first union dissolution, vary from around $30 \%$ in Italy and Poland to $81 \%$ in Sweden (Table 2). ${ }^{6}$ Differences between countries are statistically significant (Wald Chi2, $\mathrm{p}=0.0000$ ).

\footnotetext{
${ }^{4}$ There are insufficient countries to conduct a multi-level model. See Bryan and Jenkins (2013).

${ }^{5}$ We conducted sensitivity analyses using different countries as the reference category. Although regression coefficients changed, as they are expressed in relation to the reference category the substantive conclusions remain the same.

${ }^{6}$ Similar patterns are observed if we restrict the analysis to five years after first union dissolution.
} 
Table 2: Life table estimates of cumulative proportions of repartnering within ten years since first union dissolution (divorced or separated, whichever comes first), and number of years by which $25 \%, 50 \%$, and $75 \%$ of separated women have repartnered

\begin{tabular}{lcccc}
\hline Country & $\begin{array}{c}\text { Percentage of women } \\
\text { who repartnered } \\
\text { within ten years }\end{array}$ & $\mathbf{2 5 \%}$ & $\mathbf{5 0 \%}$ & $\mathbf{7 5 \%}$ \\
\hline Belgium & 68.0 & 1.9 & 4.2 & 15.3 \\
Estonia & 60.3 & 1.8 & 6.0 & 16.5 \\
France & 64.9 & 2.0 & 5.0 & \\
Hungary & 58.7 & 2.3 & 7.6 & 17.8 \\
Italy & 31.0 & 7.1 & & 12.3 \\
NDL & 67.6 & 2.3 & 4.9 & \\
Norway & 71.1 & 2.1 & 4.8 & 23.7 \\
Poland & 34.1 & 6.8 & & 8.0 \\
Russia & 62.0 & 2.1 & 6.2 & 12.7 \\
Sweden & 80.6 & 1.6 & 3.5 & \\
UK & 72.3 & 1.5 & 4.1 & \\
\hline
\end{tabular}

Note: Female birth cohort 1950-1969, within ten years since separation, women's experiences are censored at January 2005 (2003 in Italy and the Netherlands) for all countries to allow comparability across countries.

Cross-national differences in repartnering behaviour are even more pronounced when the pace of repartnering is explored, i.e., the time until $25 \%, 50 \%$, or $75 \%$ of separated women repartner. In Belgium, Estonia, France, Hungary, the Netherlands, Norway, Russia, Sweden, and the United Kingdom around a quarter of women had repartnered approximately 2 years after the separation from the first partner. By contrast, in Italy and Poland it took almost 7 years for $25 \%$ of separated women to start a second coresidential union. The median duration before repartnering (i.e., when $50 \%$ of separated women have repartnered) is the shortest in Sweden (3.5 years), followed by Belgium and the United Kingdom (around 4 years). At the other end of the spectrum, in Italy and Poland, the pace of repartnering is so slow that we do not observe median duration.

Figure 1 shows differences in the cumulative percentages of repartnering within ten years, comparing women whose first partnership was a cohabitation or marriage. In all European countries previously cohabiting women were more likely to repartner than previously married women, suggesting some fundamental distinctions between the two types of union. However, the differences in life table estimates for previously cohabiting and married women are only statistically significant (Wald Chi2, $\mathrm{p}<0.001$ ) in Italy, the Netherlands, Norway, Sweden, and the United Kingdom. Figure 1 may 
reflect heterogeneity with respect to age, children, and duration of union, all of which may reduce differences between the repartnering behaviour of the formerly cohabiting and married. We present the tables and figures in the following section to provide additional insight into how our variables of interest differ across countries and also between formerly cohabiting and married women.

Figure 1: Life table estimates of cumulative percentages of repartnering within ten years since first union dissolution (divorced or separated, whichever comes first) by first union type, women born 1950-1969

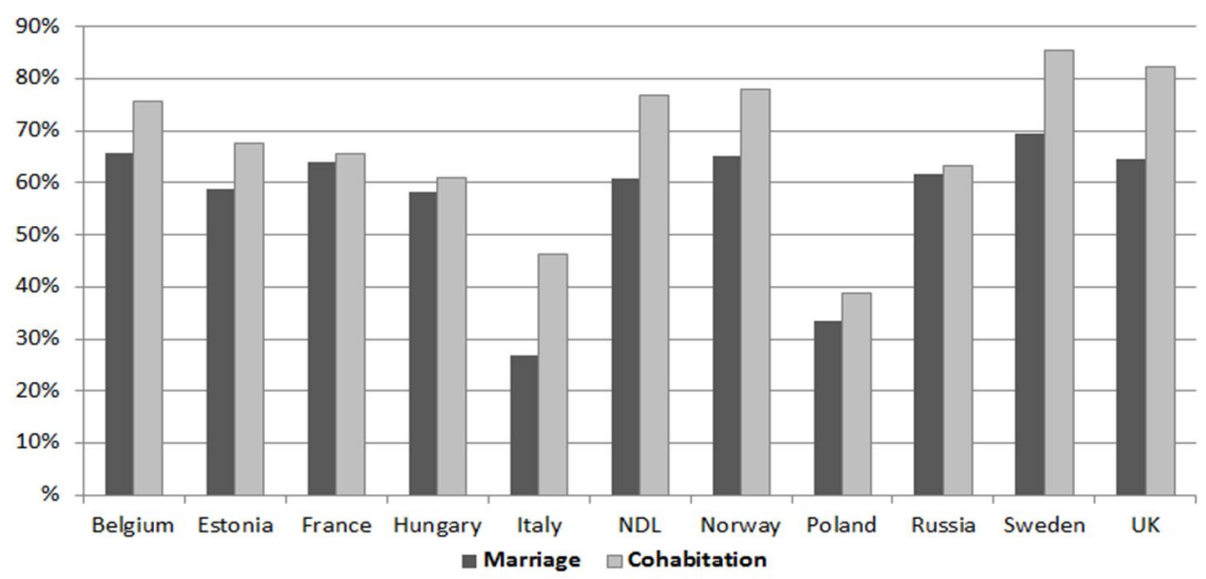

Note: Women's experiences are censored at January 2005 (2003 in Italy and the Netherlands) to allow comparability across countries. Weights have been applied if available.

\subsubsection{Demographic characteristics at time of separation}

First union type. We now turn to an analysis of the distribution of the population at risk of repartnering according to our key variables. The first two rows of Table 3 show the percentage of women whose first union dissolved, by union type, in 11 European countries. Among the 1950-1969 cohorts in all countries except Sweden, most women re-entering the partner market were previously married. The percentage of separated women who had dissolved a cohabiting first union ranges from $10 \%-12 \%$ in Hungary, Poland, and Russia to over 40\% in France, the Netherlands, and Norway and up to 66\% in Sweden where cohabitation is normative. Even though our table only shows unions which separate, these patterns reflect the variation in cohabitation across Europe (Perelli-Harris et al. 2017). 
Table 3: Percentage of women born in 1950-1969 whose first union dissolved, by variables of interest

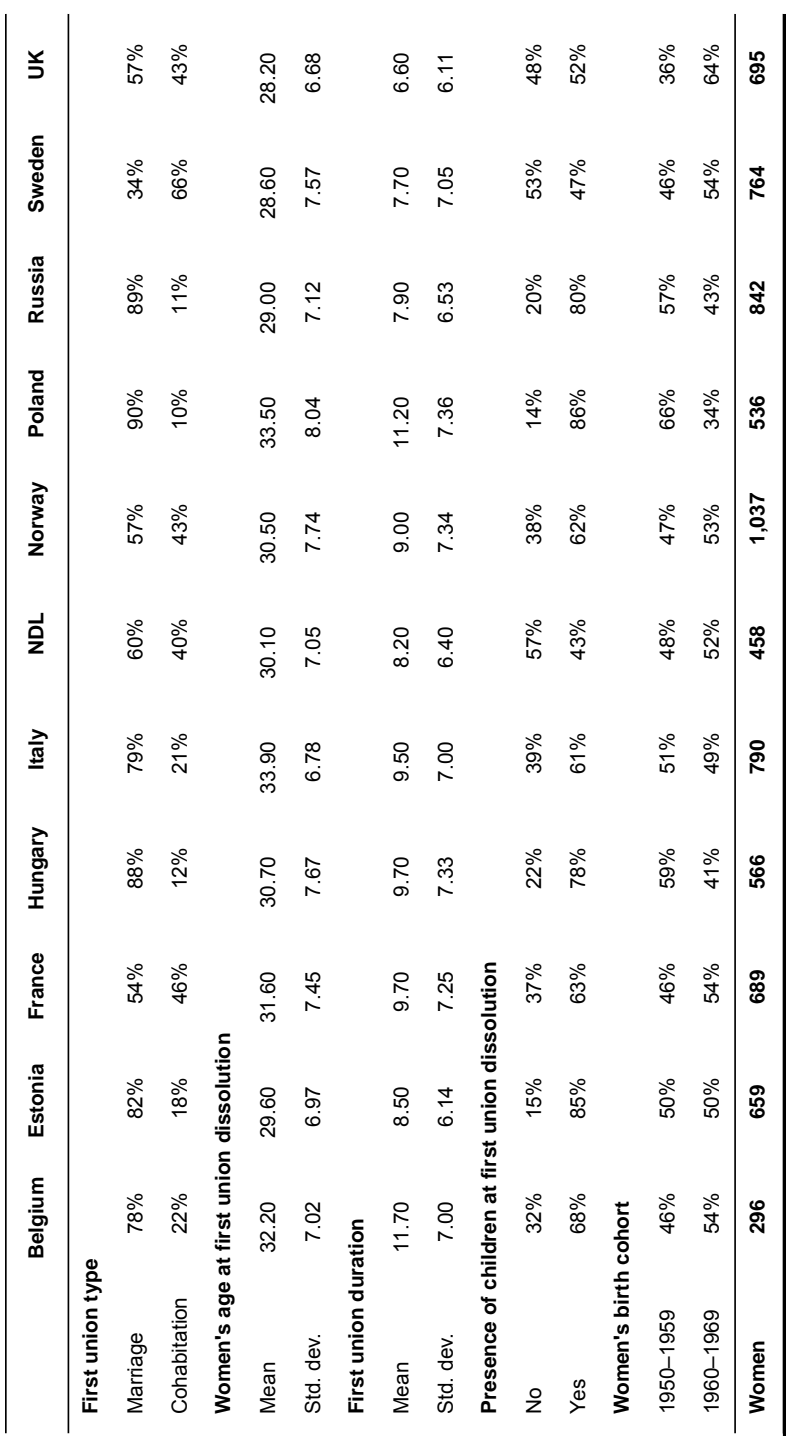

Note: Category 'marriage' encompasses women married directly and women whose first marital union was preceded by cohabitation. Women's experiences are censored at January 2005 (2003 in Italy and the Netherlands) to allow comparability across countries. Weights have been applied if available. 
Age at union dissolution. The average age at first union dissolution across Europe ranges from 28.2 years in the United Kingdom to 33.5 and 33.9 in Poland and Italy respectively (Table 3). Further examination of the distribution (not shown) suggests that in Estonia, the Netherlands, Norway, Russia, Sweden, and the United Kingdom the majority of women exposed to repartnering experienced first union dissolution under age 30, often in their early 20s. In Belgium, France, Italy, and Poland, on the other hand, the majority of separated women are in their 30s (often late 30s) when their first union dissolves.

The variation in the age at separation across Europe may be due to differences in first union type. Figure 2 shows that in all European countries divorced women are substantially older at union dissolution than previously cohabiting women. The mean age at marital first union dissolution ranges from around 29.3 in Russia to over 34.0 in Italy and Sweden, while the mean age at nonmarital union dissolution is considerably younger and varies between 25.2 years in the United Kingdom and 32.6 in Poland. Differences in mean age at union dissolution by first union type are more pronounced in Western and Northern European countries (5.5-8.5 years) where cohabitation is more common than in Southern and Eastern Europe (no more than 3.5 years).

\section{Figure 2: Mean age at first union dissolution by first union type, women born} 1950-1969

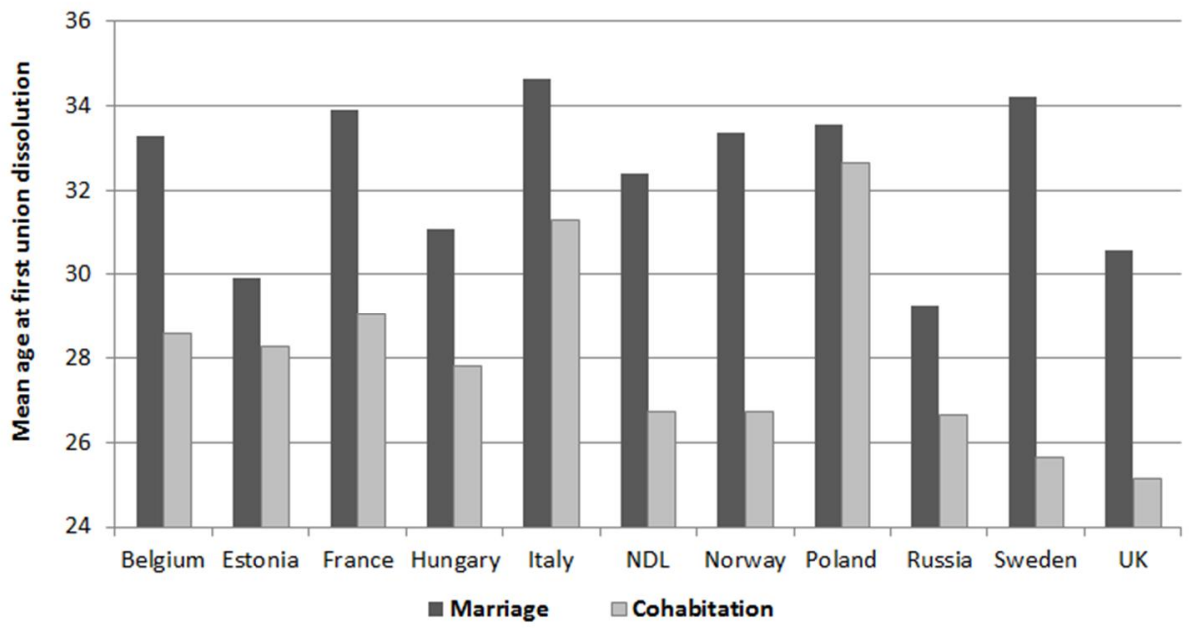

Note: Category 'marriage' encompasses women married directly and women whose first marital union was preceded by cohabitation. Women's experiences are censored at January 2005 (2003 in Italy and the Netherlands) for all countries to allow comparability across countries.Weights have been applied if available. 
First union duration. The mean duration of first union varies from 7-8 years in the United Kingdom, Sweden, Russia, and the Netherlands to over 11 years in Belgium and Poland (Table 3). However, dissolved first marital unions lasted for considerably longer than cohabiting first unions (Figure 3), corroborating previous studies that cohabitating unions are often more unstable than marital unions (Beaujouan and Ní Bhrolcháin 2011). Of interest is the particularly short length of first cohabiting partnerships in Russia (3.2 years) and the United Kingdom (2.8 years), as compared with other countries such as Belgium, France, and Poland where the average duration is over 6 years. Recall that in our analysis, marriages may have been preceded by cohabitation and hence the more stable cohabiting unions may have been more likely to transition into marriage. These patterns also reflect cross-national differences in normative expectations: In the United Kingdom and Russia, which have shorter cohabiting unions (Beaujouan and Ní Bhrolcháin 2011; Perelli-Harris and Gerber 2011), it appears to be normative to either marry or dissolve a union relatively quickly, but in the other countries it is more common to remain cohabitating for a longer period, as in France (Rault and Régnier-Loilier 2015), or the cohabiting unions may be very selective, as in Poland (Mynarska and Matysiak 2010).

\section{Figure 3: Mean first union duration by first union type, women born} 1950-1969

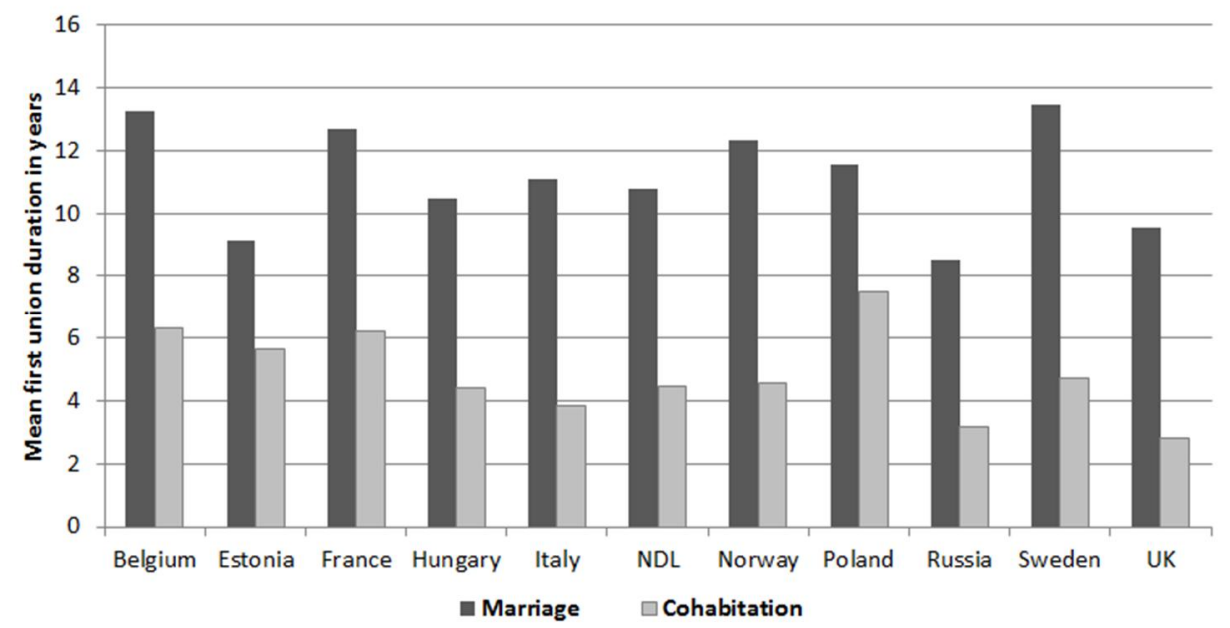

Note: Category 'marriage' encompasses women married directly and women whose first marital union was preceded by cohabitation. Women's experiences are censored at January 2005 (2003 in Italy and the Netherlands) to allow comparability across countries. Weights have been applied if available. 
Presence of children. Numerous studies have found that the presence of children at union dissolution generally has a negative effect on women's repartnering chances (Beaujouan 2012; Ivanova, Kalmijn, and Uunk 2013; Lampard and Peggs 1999; Meggiolaro and Ongaro 2008; Poortman 2007; Skew, Evans, and Gray 2009). Table 3 shows that the percentage of women who have yet to become mothers when they dissolve their first union differs considerably across countries, ranging from $15 \%$ or less in Estonia and Poland to around half in the United Kingdom and over half in the Netherlands and Sweden. In all countries, previously married women are more likely to have had children at the point of separation than previously cohabiting women, but the difference between the two is much larger in the Netherlands, where fewer than $10 \%$ of women separated from a cohabiting partner were mothers, as compared with Estonia, where over $70 \%$ of previously cohabiting women have children when they re-enter the partner market (Figure 4).

Figure 4: Presence of children at separation by first union type, women born 1950-1969

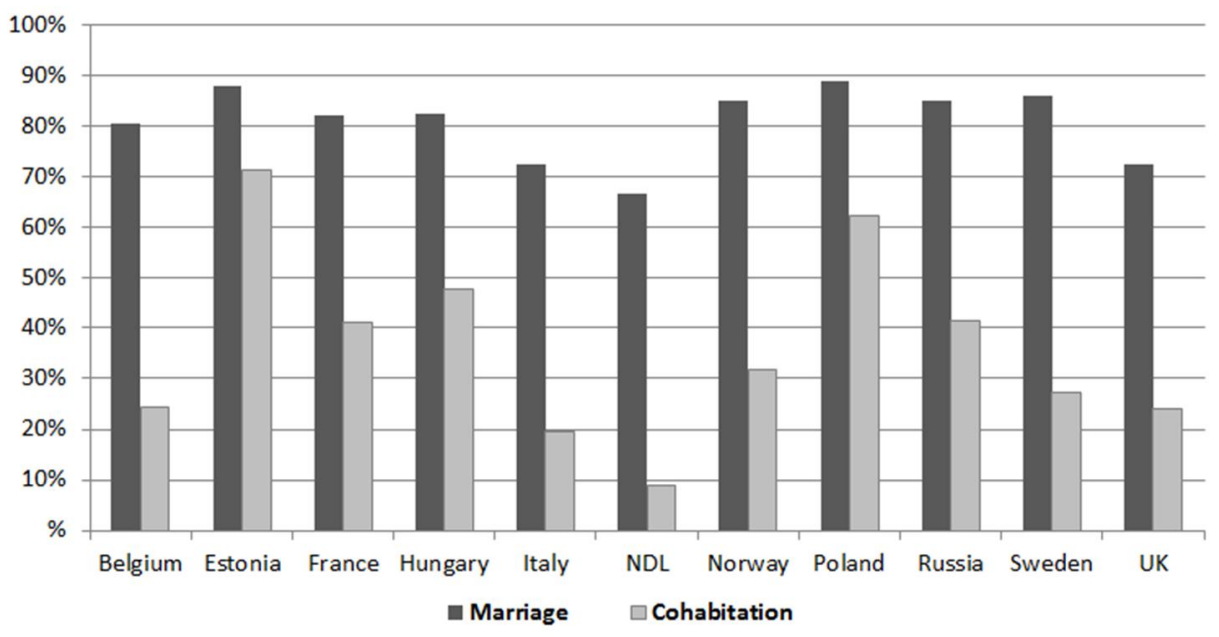

Note: Category 'marriage' encompasses women married directly and women whose first marital union was preceded by cohabitation Women's experiences are censored at January 2005 (2003 in Italy and the Netherlands) to allow comparability across countries. Weights have been applied if available.

The percentage of mothers among cohabiting women whose first unions dissolved is much lower in Western and Southern European countries (less than 30\% in Belgium, Italy, the Netherlands, Norway, Sweden, and the United Kingdom) than in Eastern Europe (Estonia, Hungary, Poland, and Russia). This result is somewhat puzzling, as 
one might expect that in countries with very strong marriage norms and a low prevalence of cohabitation the percentage of previously cohabiting women with children at union dissolution would be lower. On the one hand, the relatively high percentage of mothers among women who dissolved a cohabiting first union may result from the small sample size of cohabiting women in Poland (53 obs.). On the other hand, previous research on Eastern Europe has shown that the vast majority of women who cohabit at the start of first partnership transition into marriage before first birth (PerelliHarris et al. 2012). Therefore, women who continued to cohabit after first birth may be somewhat selective, and hence have an elevated risk of union dissolution.

\subsection{Single-country regression models}

Demographic characteristics. We now turn to models which incorporate all of the variables of interest, to show whether previously cohabiting women still have higher risks of repartnering than the previously married after including demographic controls. Table 4 shows the odds ratios from the final discrete-time hazard models for each country separately, in which all covariates are included. Once women's age, duration of the first union, and presence of children are included, the type of the first partnership is no longer significantly associated with the risk of repartnering, with the exception of France where women who were cohabiting at first union have a $30 \%$ lower risk of repartnering than women who were married. In Poland previous cohabitors have a 54\% higher risk of repartnering, but the difference is not statistically significant because of the relatively small number of cohabitors in the Polish sample.

In additional analyses (available on request), we run a series of nested models to gain further insight as to why the observed unadjusted differences between previously cohabiting and married women (seen in Figure 1) are no longer observed in the final model. The first model included partnership type and our controls (duration since separation and birth cohort). We then successively include the demographic characteristics of women at first partnership dissolution. In the Netherlands, Norway, and Sweden, once any demographic characteristics are controlled for, the effect of partnership type becomes insignificant. In the United Kingdom, once differences in age at dissolution and the presence of children are controlled for, the effect of first partnership type disappears. For Italy, differences between previous cohabitors and married women in terms of age at dissolution and the duration of the first partnership appear to mediate the relationship. In France, on the other hand, the relationship between cohabitation and repartnering becomes significant as soon as any demographic characteristics are included, suggesting that compositional aspects at time of union dissolution differ, or that the meaning of cohabitation in France is different. 
Table 4: Odds ratios of repartnering, from discrete-time hazard singlecountry models

\begin{tabular}{lcccccc}
\hline & Belgium & Estonia & France & Hungary & Italy & NDL \\
\hline First union type (ref. marriage) & & & & & \\
Cohabitation & 0.85 & 1.11 & $0.70^{* *}$ & 1.19 & 1.27 & 0.96 \\
& $(0.21)$ & $(0.16)$ & $(0.09)$ & $(0.25)$ & $(0.27)$ & $(0.16)$
\end{tabular}

Women's age at first

$\begin{array}{lcccccc}\text { union dissolution } & 0.98 & 0.91^{* * *} & 0.94^{* *} & 0.89^{* * *} & 0.94^{* * *} & 0.99 \\ & (0.02) & (0.02) & (0.02) & (0.02) & (0.02) & (0.02)\end{array}$

First union duration

$\begin{array}{lcccccc}\text { (numeric) } & 1.00 & 1.04 & 1.02 & 1.07^{* *} & 0.98 & 0.97 \\ & (0.02) & (0.02) & (0.02) & (0.03) & (0.02) & (0.02)\end{array}$

Presence of children (ref. No)

$\begin{array}{ccccccc}\text { Yes } & 0.75 & 0.95 & 0.64^{* *} & 0.81 & 0.74 & 0.63^{*} \\ & (0.15) & (0.14) & (0.09) & (0.12) & (0.15) & (0.12)\end{array}$

Duration since first union dissolution in years (ref. 2-5 years)

\begin{tabular}{lcccccc} 
Less than 2 years & 0.99 & $1.41^{* *}$ & 0.97 & 1.25 & 1.01 & 0.83 \\
& $(0.17)$ & $(0.17)$ & $(0.13)$ & $(0.18)$ & $(0.22)$ & $(0.12)$ \\
& & & & & & \\
\multirow{2}{*}{ 5-10 years } & $0.52^{* *}$ & $0.54^{* * *}$ & $0.50^{* * *}$ & $0.69^{*}$ & 0.88 & $0.59^{* *}$ \\
& $(0.11)$ & $(0.08)$ & $(0.09)$ & $(0.11)$ & $(0.20)$ & $(0.10)$
\end{tabular}

Birth cohort (ref. 1960-1969)

\begin{tabular}{lcccccc} 
1950-1959 & 0.77 & 0.83 & 0.80 & 1.16 & 0.84 & 0.80 \\
& $(0.13)$ & $(0.09)$ & $(0.10)$ & $(0.14)$ & $(0.16)$ & $(0.11)$ \\
\hline Constant & $0.036^{\star * *}$ & $0.12^{\star * *}$ & $0.12^{\star * *}$ & $0.17^{* * *}$ & $0.030^{\star * *}$ & $0.027^{* * *}$ \\
Number of women & 296 & 659 & 689 & 566 & 790 & 458 \\
Number of events & 174 & 363 & 342 & 289 & 177 & 295 \\
Person-months & 15,570 & 40,993 & 41,448 & 35,389 & 56,695 & 26,231 \\
\hline
\end{tabular}


Table 4: (Continued)

\begin{tabular}{lccccc}
\hline & Norway & Poland & Russia & Sweden & UK \\
\hline $\begin{array}{l}\text { First union type (ref. marriage) } \\
\text { Cohabitation }\end{array}$ & 1.06 & 1.54 & 0.78 & 1.03 & 1.21 \\
& $(0.11)$ & $(0.40)$ & $(0.14)$ & $(0.12)$ & $(0.18)$ \\
& & & & & \\
$\begin{array}{l}\text { Women's age at first } \\
\text { union dissolution }\end{array}$ & $0.92^{* * *}$ & $0.87^{* * *}$ & $0.93^{* * *}$ & $0.93^{* * *}$ & $0.92^{* * *}$ \\
& $(0.01)$ & $(0.03)$ & $(0.01)$ & $(0.01)$ & $(0.02)$ \\
$\begin{array}{l}\text { First union duration } \\
\text { (numeric) }\end{array}$ & $1.06^{* * *}$ & $1.09^{*}$ & 1.01 & & \\
& $(0.02)$ & $(0.03)$ & $(0.02)$ & $(0.02)$ & $(0.03)$
\end{tabular}

Presence of children (ref. No)

\begin{tabular}{|c|c|c|c|c|c|}
\hline Yes & $\begin{array}{l}0.66^{\star \star *} \\
(0.07)\end{array}$ & $\begin{array}{c}0.68 \\
(0.15)\end{array}$ & $\begin{array}{c}0.84 \\
(0.12)\end{array}$ & $\begin{array}{c}0.76^{*} \\
(0.09)\end{array}$ & \\
\hline
\end{tabular}

Duration since first union dissolution in years (ref. 2-5 years)

$\begin{array}{lccccc}\text { Less than 2 years } & 0.82^{*} & 1.23 & 1.34^{*} & 0.88 & 1.27 \\ & (0.08) & (0.26) & (0.17) & (0.08) & (0.18) \\ & & & & & \\ & 0.65^{* * *} & 1.12 & 0.80 & 0.70^{* *} & 0.72 \\ 5-10 \text { years } & (0.07) & (0.22) & (0.11) & (0.08) & (0.12)\end{array}$

Birth cohort (ref. 1960-1969)

\begin{tabular}{lrrrrr}
$1950-1959$ & \multicolumn{1}{c}{$0.80^{*}$} & 0.99 & 0.89 & 0.87 & \multicolumn{1}{c}{0.84} \\
& \multicolumn{1}{c}{$(0.08)$} & $(0.18)$ & $(0.09)$ & $(0.08)$ & \multicolumn{1}{c}{$(0.12)$} \\
\hline Constant & $0.14^{* * *}$ & $0.13^{* *}$ & $0.084^{* * *}$ & $0.13^{* * *}$ & $0.11^{* * *}$ \\
Number of women & 1,037 & 536 & 842 & 764 & 695 \\
Number of events & 652 & 145 & 424 & 555 & 425 \\
Person-months & 57,562 & 41,149 & 56,672 & 37,166 & 42,137 \\
\hline
\end{tabular}

Note: Exponentiated coefficients. Significance level: ${ }^{*} p<0.05$, ${ }^{* *} p<0.01,{ }^{* *} p<0.001$. Standard errors in parenthesis.

Female birth cohort 1950-1969, within ten years since separation. Women's experiences are censored at January 2005 (2003 in Italy and the Netherlands) to allow comparability across countries. Category "marriage" encompasses women married directly and women whose first marital union was preceded by cohabitation. Weights have been applied if available. 
Age at first union dissolution has a strong, negative association with repartnering in all countries except Belgium and the Netherlands, net of other factors. For each additional year of age, the risk of repartnering decreases by $6 \%$ in Italy and France and by up to $13 \%$ in Poland. Mothers differ significantly in their repartnering behaviour compared to childless women in France, the Netherlands, Norway, Sweden, and the United Kingdom. The risk of repartnering for mothers, compared with childless women, ranges from $24 \%$ lower in Sweden to $53 \%$ lower in the United Kingdom. In the remaining countries, where the effect of the presence of children at union dissolution is not significant, the odds ratios of repartnering for mothers are also substantially below one. These findings corroborate previous research on selected countries (Beaujouan 2012; de Graaf and Kalmijn 2003; Ivanova, Kalmijn, and Uunk 2013; Lampard and Peggs 1999; Poortman 2007; Skew, Evans, and Gray 2009). In Belgium and Poland the lack of statistical significance likely reflects small sample size. For example, Vanassche and colleagues (2015) have analysed a much larger sample of women in Flanders (the Northern region of Belgium) and found a strong negative age effect on repartnering.

The duration of first union has a significant effect on women's repartnering in 5 out of 11 countries (Table 4). In Hungary, Norway, Poland, Sweden, and the United Kingdom each additional year of first union increases the risk of repartnering, by $3 \%$ in Sweden up to $9 \%$ in Poland. Our results suggest that in some European countries, women in long first unions may be more family-oriented and/or perceived as more committed to a union (Poortman 2007). ${ }^{7}$

Other control variables. Duration since separation, which is a base line hazard in the models, has a significant effect on women's repartnering in 8 out of 11 countries (Table 4). The risk of repartnering generally decreases over time, and 5-10 years following separation it ranges from 30\% lower in Sweden and Hungary to 50\% lower in France than 2-5 years after separation from first partner. In most countries the risk of repartnering in the first 2 years following separation is not significantly different from the risk of second union formation 2-5 years after separation (ref. category). The differences are found in Estonia and Russia, where the risk of repartnering in the first couple of years after separation is $41 \%$ and $34 \%$ higher, respectively, than in the reference category, and in Norway, where somewhat surprisingly the highest risk of repartnering is observed $2-5$ years after separation.

Furthermore, except in Norway, the odds ratios indicate no significant differences in repartnering behaviour across birth cohorts once women's age, the presence of children at first union dissolution, and first union type and duration are included. A series of single-country discrete-time hazard models estimated in the model-building

\footnotetext{
${ }^{7}$ Duration of first union and age at union dissolution are to some extent correlated, but sensitivity analyses show that the effect of the variables of interest do not change when age and union duration are included in the model, although union duration itself may change slightly in some countries.
} 
process (available on request) show that controlling only for duration since separation and first union type, in most countries women born in 1960-1969 have significantly higher risks of repartnering. However, the effect becomes insignificant once age at union dissolution is included in the model, suggesting that more recent birth cohorts are repartnering to a greater extent because they are splitting up with their first partners at a younger age.

\subsection{Pooled regression model}

In the second set of analyses we examine whether women's past demographic experiences have the same effect on repartnering in all European countries. Using a pooled dataset of 11 countries, we estimate a discrete-time hazard model with interaction terms between the country and each of the explanatory variables. Table 5 shows the main effects and significant interactions. The significant interaction effect between country and first partnership type suggests that the relationship between first partnership type and the chance of repartnering in Estonia, Hungary, Italy, Norway, Poland, Sweden, and the United Kingdom is significantly different to the relationship seen for France.

Table 5: Odds ratios from pooled model of 11 countries with main effects and significant interaction effects

\begin{tabular}{lll}
\hline & Odds ratios & Std. error \\
\hline Country (ref. France) & & \\
Belgium & 0.31 & $(0.19)$ \\
Estonia & 1.05 & $(0.61)$ \\
Hungary & 1.43 & $(0.91)$ \\
Italy & $0.26^{*}$ & $(0.17)$ \\
NDL & $0.23^{\star *}$ & $(0.13)$ \\
Norway & 1.22 & $(0.63)$ \\
Poland & 1.09 & $(0.82)$ \\
Russia & 0.71 & $(0.39)$ \\
Sweden & 1.13 & $(0.61)$ \\
UK & 0.91 & $(0.54)$ \\
\hline
\end{tabular}


Table 5: (Continued)

\begin{tabular}{|c|c|c|}
\hline & Odds ratios & Std. error \\
\hline \multicolumn{3}{|l|}{ First union type (ref. marriage) } \\
\hline Cohabitation & $0.70^{* *}$ & $(0.09)$ \\
\hline Cohabitation * Estonia & $1.58^{*}$ & $(0.31)$ \\
\hline Cohabitation * Hungary & $1.70^{*}$ & $(0.42)$ \\
\hline Cohabitation * Italy & $1.82^{*}$ & $(0.45)$ \\
\hline Cohabitation * Norway & $1.52^{*}$ & $(0.26)$ \\
\hline Cohabitation * Poland & $2.20^{\star *}$ & $(0.64)$ \\
\hline Cohabitation * Sweden & $1.47^{*}$ & $(0.26)$ \\
\hline Cohabitation * UK & $1.73^{\star *}$ & $(0.35)$ \\
\hline \multicolumn{3}{|l|}{ Women's age at first union dissolution } \\
\hline Age at union dissolution * Hungary & $0.94^{*}$ & $(0.03)$ \\
\hline Age at union dissolution * NDL & $1.05^{*}$ & $(0.03)$ \\
\hline Age at union dissolution * Poland & $0.93^{*}$ & $(0.03)$ \\
\hline First union duration (numeric) & 1.02 & $(0.02)$ \\
\hline \multicolumn{3}{|l|}{ Presence of children (ref. no) } \\
\hline Yes & $0.64^{* *}$ & $(0.09)$ \\
\hline \multicolumn{3}{|l|}{ Duration since separation (ref. 2-5 years) } \\
\hline Less than 2 years & 0.97 & $(0.13)$ \\
\hline $5-10$ years & $0.50^{* * *}$ & $(0.09)$ \\
\hline Less than 2 years * Estonia & $1.45^{*}$ & $(0.27)$ \\
\hline $5-10$ years * Italy & $1.77^{*}$ & $(0.51)$ \\
\hline $5-10$ years * Poland & $2.27^{\star *}$ & $(0.61)$ \\
\hline $5-10$ years * Russia & $1.62^{*}$ & $(0.36)$ \\
\hline \multicolumn{3}{|l|}{ Birth cohort (ref. 1960-1969) } \\
\hline $1950-1959$ & 0.80 & $(0.10)$ \\
\hline Birth cohort 1950-1959 * Hungary & $1.44^{*}$ & $(0.26)$ \\
\hline Constant & $0.12^{\star \star \star}$ & $(0.05)$ \\
\hline Number of women & \multicolumn{2}{|c|}{7,332} \\
\hline Number of event & \multicolumn{2}{|c|}{3,841} \\
\hline Person-months & \multicolumn{2}{|c|}{451,012} \\
\hline
\end{tabular}

Note: Exponentiated coefficients. Significance level: ${ }^{*} p<0.05,{ }^{* *} p<0.01,{ }^{* \star *} p<0.001$. Standard errors in parentheses.

Female birth cohort 1950-1969, within ten years since separation. Women's experiences are censored at January 2005 (2003 in Italy and the Netherlands) to allow comparability across countries. Category "marriage" encompasses women married directly and women whose first marital union was preceded by cohabitation. Weights have been applied if available. 
Figure 5 shows the predicted probabilities of repartnering according to first partnership type for childless women, with other variables held at their mean value (for continuous variables), cohort 1960-1969, and duration since separation set to $2-5$ years.

\section{Figure 5: $\quad$ Predicted probabilities of repartnering by first union type}

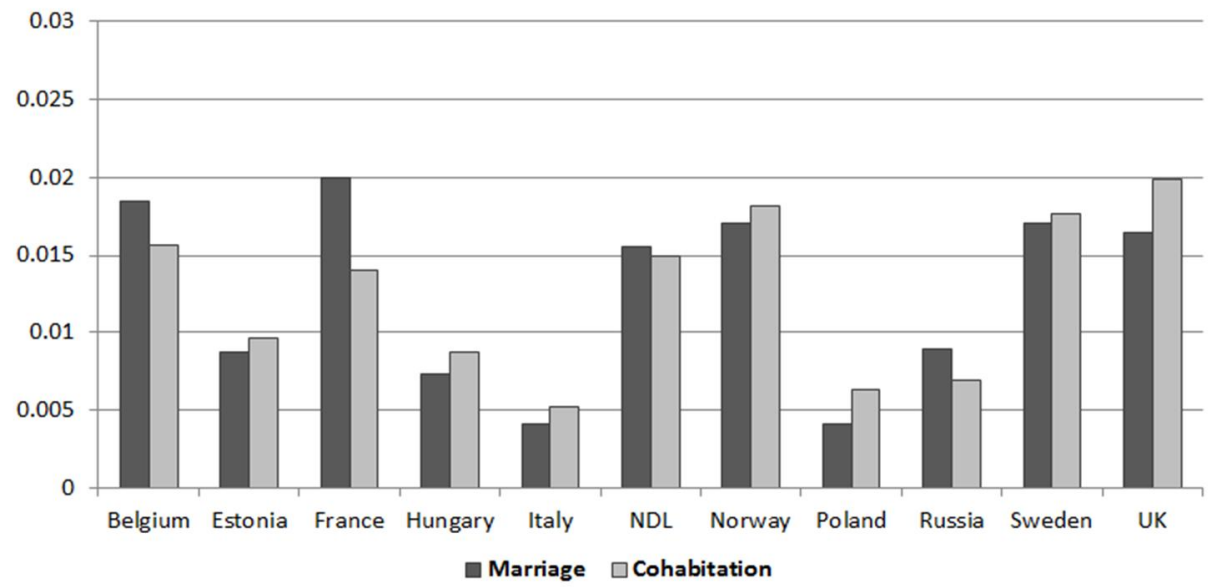

Note: Predicted probabilities are calculated for childless women using the mean age at first union dissolution for all countries (age 30.4), mean first union duration (8.7 years), birth cohort of 1960-1969 and the duration since separation set to 2-5 years. Based upon pooled model of 11 countries. Category 'marriage' encompasses women married directly and women whose first marital union was preceded by cohabitation. Women's experiences are censored at January 2005 (2003 in Italy and the Netherlands) to allow comparability across countries. Weights have been applied if available.

The highest monthly probabilities of repartnering are observed in Belgium, France, the Netherlands, Norway, Sweden, and the United Kingdom, and the lowest in Poland and Italy. In most countries, once other variables are controlled for, the chances of repartnering for previously cohabiting women are similar (or only very slightly higher) to those of divorcees. France (and to a lesser extent Belgium and Russia) stands out from the other countries, since here previously married women appear far more likely to repartner.

We do not see any significant interaction between presence of children and country, which tells us that the dampening effect of children on repartnering is universal (Table 5). We do, however, find significant interactions between country and time since dissolution. In most countries the risk of repartnering is similarly high in the first five years following separation. A difference is seen for Estonia, however, where risk of repartnering is $45 \%$ higher in the first couple of years than in the subsequent few years. In many countries the risk of repartnering is significantly lower at longer 
durations subsequent to dissolution. However, this is not the case for Italy, Poland, and Russia. Finally, the interactions between country and age at dissolution shown in Table 5 suggest that most countries exhibit a negative relationship between age at dissolution and repartnering, and that this negative relationship is particularly strong in Poland and Hungary. By contrast, in the Netherlands age at dissolution does not affect the risk of repartnering, net of other factors.

\section{Discussion}

This study describes repartnering behaviour across 11 European countries and examines whether the effects of key factors associated with second union formation differ across countries. Previous studies have examined individual covariates associated with repartnering, but none have shown the extent of the variation across Europe. Here we find substantial differences: For example, $80 \%$ of women repartner within ten years in Sweden, while around $30 \%$ do so in Italy and Poland. These differences suggest that the experiences of women in the repartnering market are context-specific, possibly determined by the economic or social need to repartner, the stigma attached to divorced women, or characteristics of the first union such as duration and children.

In addition, few studies have provided a basic comparison of the demographic circumstances of women at the time of union dissolution. Such an analysis is important, because it indicates compositional differences in the population at risk of repartnering and may help to explain variation in repartnering levels across countries. For example, age at separation varies considerably across Europe, with the mean age ranging from 28 in the United Kingdom to almost 34 in Italy and Poland. The percentage of childless women exposed to repartnering is much higher in Northern and Western Europe than in Eastern European countries. Furthermore, the percentage of women who separated from a cohabiting first partner varies, from around $10 \%$ in most Eastern and Southern European countries to over $40 \%$ in France, the Netherlands, Norway, and the United Kingdom and up to $66 \%$ in Sweden. These figures indicate considerable heterogeneity in repartnering dynamics, not only in the level of repartnering but also in the characteristics of the women available to repartner.

Our next aim was to examine whether the relationships between key demographic variables and repartnering are the same or different across countries. In particular, we focus on the role of cohabitation in the repartnering process. While the institution of marriage has changed dramatically over the past few decades, cohabitation is altering the nature of relationships (Perelli-Harris et al. 2014) and has an even more ambiguous meaning for partnership formation and dissolution (Cherlin 2004). Previous studies have found significant differences between marriage and cohabitation: For example, 
cohabitors have more liberal or nonconformist values (Surkyn and Lesthaeghe 2004), a tendency to keep resources separate (Lyngstad, Noack, and Tufte 2011), lower subjective well-being (Soons and Kalmijn 2009), and lower second birth rates (PerelliHarris 2014). These differences may persist when formerly cohabiting individuals search for and settle down with new partners.

Our findings do show raw differences in repartnering behaviour between those whose first partnerships were cohabitation or marriage. In most countries previously cohabiting women repartner significantly more quickly than the previously married. However, we also find that cohabitors tend to have a younger mean age at union dissolution and shorter partnerships, and are less likely to have children. Once we use discrete-time hazard models to control for these characteristics, the type of the dissolved first union no longer matters for women's repartnering (with the exception of France). Thus, our results suggest that the primary reason that previously cohabiting and married women differ in repartnering behaviour is due to basic demographic characteristics, not because the experience of cohabitation changes their behaviour or because of more complicated selection mechanisms. Note, however, that we examine union type at the time of union dissolution; women in the most solid cohabiting unions may marry and stay in a marital union longer, while those in more fragile unions may separate before marriage. This may lead to selection of the strongest unions into marriage and different characteristics for the people who do not marry. Nonetheless, the consistent lack of difference by union type across countries is striking, suggesting a far more important role for the other demographic characteristics.

We do observe one exception: In France previously married women have about a one-third higher risk of repartnering than cohabiting women, after controlling for demographic characteristics. The fact that cohabitors in France have lower risks of repartnering is somewhat puzzling. Similar to marriage, cohabitation in France is widespread, often of long duration, and a common setting for childbearing (Köppen 2011; Rault and Régnier-Loilier 2015). Religion, however, may play an important role in marital decisions, since those who are more religious are more likely to marry (Régnier-Loilier and Prioux 2015). We therefore speculate that married people are more likely to be family-oriented or to have conservative, religious values, which are related to repartnering more quickly; however, more research is needed to better understand cohabitation and marriage in France.

Our results on the other key demographic characteristics corroborate most previous findings and show remarkable consistency across countries. The singlecountry models are consistent with the hypothesis that having at least one child is a barrier to repartnering; the effect is not statistically significant in some countries, but the coefficient is always negative and similar across countries. Unsurprisingly, the interaction terms in the pooled model show no difference between any of the countries 
and France, suggesting a universal effect across countries. While these results are consistent with previous studies on selected countries (Beaujouan 2012; de Graaf and Kalmijn 2003; Ivanova, Kalmijn, and Uunk 2013; Lampard and Peggs 1999; Poortman 2007; Skew, Evans, and Gray 2009; Vanassche et al. 2015), it is still remarkable that children are universally an impediment to forming a new partnership. Our results suggest that despite cross-national differences in welfare policies, childcare availability, and the stigma of divorce, children reduce a woman's attractiveness in the partner market or, conversely, make a mother less willing to bring a new partner into her life. However, childless women may also be more likely to repartner in order to achieve their fertility intentions.

Another factor that is relatively consistent across countries is women's age at union dissolution. The single-country models show consistent effects, despite variation in the age at union dissolution. Although the effect is not significant in Belgium and the Netherlands, we urge caution regarding this result because of small sample size; other studies do show an age effect (de Graaf and Kalmijn 2003; Poortman 2007; Vanassche et al. 2015). However, our results are generally in line with prior studies on Western societies. Further work is needed to unravel why age is so important: Is it physical attractiveness or the ability to have additional children that reduces older women's attractiveness to a potential partner (Beaujouan 2012; de Graaf and Kalmijn 2003; Ivanova, Kalmijn, and Uunk 2013; Theunis, Pasteels, and Van Bavel 2015; Vanassche et al. 2015)? Or is it more the case that older women do not have a strong need to repartner because they are more economically/emotionally independent, or might prefer not to repartner due to a bad experience with divorce (Perelli-Harris et al. 2017)? In any case, it is clear that there are strong effects across all countries.

Some limitations of this study need to be acknowledged. First, each of the surveys in the Harmonized Histories suffers from its own limitations, such as response rates or missing information (for details, see Perelli-Harris, Kreyenfeld, and Kubisch 2010). Second, retrospective data, in particular reporting of past cohabitating unions, may be subject to recall error or underreporting (Teitler, Reichman, and Koball 2006; Hayford and Morgan 2008). Third, the relatively small number of cohabiting women does not allow us to include interaction effects with first union type. The effects shown in the models are averages, and interacting partnership type with the other demographic factors may reveal important nonlinearities. For example, the repartnering behaviour of young cohabiting women may differ from that of older cohabiting women. Finally, our data limits the age range and period that we can examine to the 1950-1969 cohorts. We can only investigate repartnering in middle age, and the repartnering behaviour of older women may be different, especially if the women have been in long-term marriages. We are also unable to analyse the repartnering behaviour of more recent cohorts, who have experienced higher levels of cohabitation, union dissolution, and, indeed, serial 
partnerships (Lichter and Qian 2008; Lichter, Turner, and Sassler 2010; Bukodi 2012; Vespa 2014).

We have only been able to focus on women. Men have a strong preference for partnering with younger women (England and McClintock 2009) and the effects of men's demographic characteristics at union dissolution on second union formation may differ to those reported for women. Recent changes in legislation regarding shared custody of dependent children that aim to equalise parental rights in many European countries, for example, in Belgium, the Netherlands, and Sweden (Sodermans et al. 2013; Spruijt and Duindam 2009; Vanassche et al. 2015), may mean that men's repartnering behaviour could in future become more similar to women's. Thus, further research is needed on gender differences in second union formation.

Over the past few decades, partnership formation and dissolution have changed dramatically across Europe. Nonetheless, partnership patterns appear to be diverging more across countries than converging (Billari and Liefbroer 2010; Perelli-Harris and Lyons-Amos 2016). Here, we find that repartnering behaviour is no different: The levels differ considerably from country to country. However, we also find remarkable consistency in the effects of basic demographic characteristics. Some aspects, in particular a woman's age at union dissolution and whether she has children, make a fundamental difference to her chances of forming a second union, but others, such as whether she dissolved a cohabiting or marital union, do not seem to matter. Therefore, future research needs to investigate to what extent other individual-level factors, for example socioeconomic status or parental background, are consistent across countries, and, importantly, which contextual factors - social, cultural, political, or economic explain the large differences we observe in repartnering behaviour.

\section{Acknowledgements}

The research leading to these results has received funding from the European Research Council under the European Union's Seventh Framework Programme (FP7/20072013)/ERC grant agreement $n^{\circ} 263794$ CHILDCOHAB. Ann Berrington's contribution to this work received support from the ESRC Centre for Population Change (ES/K007394/1). 


\section{References}

Aassve, A., Betti, G., Mazzuco, S., and Mencarini, L. (2007). Marital disruption and economic well-being: A comparative analysis. Journal of the Royal Statistical Society: Series A (Statistics in Society) 170(3): 781-799. doi:10.1111/j.1467985X.2007.00483.x.

Allan, G., Crow, G., and Hawker, S. (2011). Stepfamilies. New York: Palgrave Macmillan. doi:10.1057/9780230308671.

Allison, P.D. (1982). Discrete-time methods for the analysis of event histories. Sociological Methodology 13: 61-98. doi:10.2307/270718.

Amato, P.R. (2000). The consequences of divorce for adults and children. Journal of Marriage and Family 62(4): 1269-1287. doi:10.1111/j.1741-3737.2000.012 69.x.

Andreß, H.-J., Borgloh, B., Bröckel, M., Giesselmann, M., and Hummelsheim, D. (2006). The economic consequences of partnership dissolution: A comparative analysis of panel studies from Belgium, Germany, Great Britain, Italy, and Sweden. European Sociological Review 22(5): 533-560. doi.org/10.1093/esr/ jc1012.

Beaujouan, É. (2012). Repartnering in France: The role of gender, age, and past fertility. Advances in Life Course Research 17(2): 69-80. doi.org/10.1016/j.alcr. 2012.03.001.

Beaujouan, É. and Ní Bhrolcháin, M. (2011). Cohabitation and marriage in Britain since the 1970s. Population Trends 145(1): 35-59. doi:10.1057/pt.2011.16.

Beaujouan, E. and Solaz, A. (2013). Racing against the biological clock? Childbearing and sterility among men and women in second unions in France. European Journal of Population 29(1): 39-67. doi:10.1007/s10680-012-9271-4.

Beaumont, K. and Manson, P. (2014). Child maintenance systems in EU member states from a gender perspective: In-depth anaysis for the FEMM Committee. Brussels: European Parliament.

Becker, G.S., Landes, E.M., and Michael, R.T. (1977). An economic analysis of marital instability. Journal of Political Economy 85(6): 1141-1187. doi:10.1086/260 631.

Bernhardt, E. and Goldscheider, F. (2002). Children and union formation in Sweden. European Sociological Review 18(3): 289-299. doi:10.1093/esr/18.3.289. 
Billari, F. and Liefbroer, A. (2010). Towards a new pattern of transition to adulthood? Advances in Life Course Research 15(2): 59-75. doi:10.1016/j.alcr.2010.10.003.

Billari, F.C. (2015). Integrating macro-and micro-level approaches in the explanation of population change. Population Studies 69(supp.1): 11-20. doi:10.1080/003247 28.2015.1009712.

Blanc, A.K. (1987). The formation and dissolution of second unions: Marriage and cohabitation in Sweden and Norway. Journal of Marriage and Family 49(2): 391-400. doi:10.2307/352308.

Bryan, M.L. and Jenkins, S.P. (2013). Regression analysis of country effects using multilevel data: A cautionary tale. Bonn: Institute for the Study of Labor (IZA Discussion Paper 7583).

Bukodi, E. (2012). Serial cohabitation among men in Britain: Does work history matter? European Journal of Population 28(4): 441-466. doi:10.1007/s10680012-9274-1.

Bumpass, L.L., Sweet, J., and Martin, T.C. (1990). Changing patterns of remarriage. Journal of Marriage and Family 52(3): 747-756. doi:10.2307/352939.

Cherlin, A.J. (2004). The deinstitutionalization of American marriage. Journal of Marriage and Family 66(4): 848-861. doi:10.1111/j.0022-2445.2004.00058.x.

Cunningham, M. and Thornton, A. (2005). The influence of union transitions on white adults' attitudes toward cohabitation. Journal of Marriage and Family 67(3): 710-720. doi:10.1111/j.1741-3737.2005.00164.x.

de Graaf, P.M. and Kalmijn, M. (2003). Alternative routes in the remarriage market: Competing-risk analyses of union formation after divorce. Social Forces 81(4): 1459-1498. doi:10.1353/sof.2003.0052.

de Regt, S., Mortelmans, D., and Marynissen, T. (2012). Financial consequences of relationship dissolution: A longitudinal comparison of formerly married and unmarried cohabiting men and women. Sociology 47(1): 90-108. doi:10.1177/ 0038038512453793 .

Dewilde, C. (2002). The financial consequences of relationship dissolution for women in Western Europe. In: Ruspini, E. and Dale, A. (eds.). The gender dimension of social change: The contribution of dynamic research to the study of women's life courses. Bristol: Policy Press: 81-110. doi:10.1332/policypress/978186134 3321.003.0005. 
Dewilde, C. and Uunk, W. (2008). Remarriage as a way to overcome the financial consequences of divorce: A test of the economic need hypothesis for European women. European Sociological Review 24(3): 393-407. doi:10.1093/esr/jen025.

England, P. and McClintock, E.A. (2009). The gendered double standard of aging in US marriage markets. Population and Development Review 35(4): 797-816. doi:10.1111/j.1728-4457.2009.00309.x.

Gałęzewska, P. (2016). Repartnering dynamics and fertility in new partnerships in Europe and the United States. [PhD thesis]. Southampton: University of Southampton, Faculty of Social, Human and Mathematical Sciences, Division of Social Statistics and Demography.

Gelissen, J. (2003). Cross-national differences in public consent to divorce: Effects of cultural, structural, and compositional factors. In: Arts, W.A., Hagenaars, J.A., Halman, L., van de Donk, W., and van Schail, T. (eds.). The cultural diversity of European unity: Findings, explanations, and reflections from the European Values Study. Leiden: Brill: 339-370.

Goldscheider, F. and Kaufman, G. (2006). Willingness to stepparent: Attitudes about partners who already have children. Journal of Family Issues 27(10): 14151436. doi:10.1177/0192513X06289646.

Goldscheider, F., Kaufman, G., and Sassler, S. (2009). Navigating the 'new' marriage market: How attitudes toward partner characteristics shape union formation. Journal of Family Issues 30(6): 719-737. doi:10.1177/0192513X09331570.

Goldscheider, F. and Sassler, S. (2006). Creating stepfamilies: Integrating children into the study of union formation. Journal of Marriage and Family 68(2): 275-291. doi:10.1111/j.1741-3737.2006.00252.x.

Hajnal, J. (1965). European marriage pattern in perspective. In: Glass, D.V. and Eversley, D.E.C. (eds.). Population in history: Essays in historical demography. Chicago: Aldine: 101-143.

Hajnal, J. (1982). Two kinds of preindustrial household formation system. Population and Development Review 8(3): 449-494. doi:10.2307/1972376.

Hayford, S.R. and Morgan, S.P. (2008). The quality of retrospective data on cohabitation. Demography 45(1): 129-141. doi:10.1353/dem.2008.0005.

Heuveline, P., Timberlake, J.M., and Furstenberg, F.F., Jr. (2003). Shifting childrearing to single mothers: Results from 17 Western countries. Population and Development Review 29(1): 47-71. doi:10.1111/j.1728-4457.2003.00047.x. 
Ivanova, K., Kalmijn, M., and Uunk, W. (2013). The effect of children on men's and women's chances of re-partnering in a European context. European Journal of Population 29(4): 417-444. doi:10.1007/s10680-013-9294-5.

Jansen, M., Mortelmans, D., and Snoeckx, L. (2009). Repartnering and (re)employment: Strategies to cope with the economic consequences of partnership dissolution. Journal of Marriage and Family 71(5): 1271-1293. doi:10.1111/j.1741-3737.2009.00668.x.

Jaschinski, I. (2011). Der Übergang in eine nacheheliche Partnerschaft: Eine vergleichende Analyse zwischen Männern und Frauen auf Basis des deutschen Generations and Gender Survey. Zeitschrift für Familienforschung 23(2): 219240 .

Kalmijn, M. (2007). Explaining cross-national differences in marriage, cohabitation, and divorce in Europe, 1990-2000. Population Studies 61(3): 243-263. doi:10.1080/00324720701571806.

Katus, K., Puur, A., Põldma, A., and Sakkeus, L. (2007). First union formation in Estonia, Latvia, and Lithuania: Patterns across countries and gender. Demographic Research 17(10): 247-300. doi:10.4054/DemRes.2007.17.10.

Kennedy, S. and Ruggles, S. (2014). Breaking up is hard to count: The rise of divorce in the United States, 1980-2010. Demography 51(2): 1-12. doi:10.1007/s13524013-0270-9.

Kiernan, K. (2001). The rise of cohabitation and childbearing outside marriage in Western Europe. International Journal of Law, Policy, and the Family 15(1): 121. doi:10.1093/lawfam/15.1.1.

Kiernan, K. (2004). Unmarried cohabitation and parenthood in Britain and Europe. Law and Policy 26(1): 33-55. doi:10.1111/j.0265-8240.2004.00162.x.

Koo, H.P., Suchindran, C.M., and Griffith, J.D. (1984). The effects of children on divorce and re-marriage: A multivariate analysis of life table probabilities. Population Studies 38(3): 451-471. doi:10.2307/2174134.

Köppen, K. (2011). Marriage and cohabitation in Western Germany and France. [PhD thesis]. Rostock: Universität Rostock, Wirtschafts- und Sozialwissenschaftliche Fakultät.

Lampard, R. and Peggs, K. (1999). Repartnering: The relevance of parenthood and gender to cohabitation and remarriage among the formerly married. The British Journal of Sociology 50(3): 443-465. doi:10.1080/000713199358644. 
Lappegård, T. and Noack, T. (2015). The link between parenthood and partnership in contemporary Norway: Findings from focus group research. Demographic Research 32(9): 287-310. doi:10.4054/DemRes.2015.32.9.

Lesthaeghe, R. (2010). The unfolding story of the second demographic transition. Population and Development Review 36(2): 211-251. doi:10.1111/j.1728-4457. 2010.00328.x.

Lichter, D.T. and Qian, Z. (2008). Serial cohabitation and the marital life course. Journal of Marriage and Family 70(4): 861-878. doi:10.1111/j.1741-3737. 2008.00532.x.

Lichter, D.T., Turner, R.N., and Sassler, S. (2010). National estimates of the rise in serial cohabitation. Social Science Research 39(5): 754-765. doi:10.1016/j.ss research.2009.11.002.

Liefbroer, A. and Dourleijn, E. (2006). Unmarried cohabitation and union stability: Testing the role of diffusion using data from 16 European countries. Demography 43(2): 203-221. doi:10.1353/dem.2006.0018.

Liefbroer, A.C. and Fokkema, T. (2008). Recent trends in demographic attitudes and behaviour: Is the second demographic transition moving to Southern and Eastern Europe? In: Surkyn, J., Deboosere, P., and Van Bavel, J. (eds.). Demographic challenges for the $21^{\text {st }}$ century: A state of the art in demography. Brussels: VUB Press: $115-141$.

Lyngstad, T.H., Noack, T., and Tufte, P.A. (2011). Pooling of economic resources: A comparison of Norwegian married and cohabiting couples. European Sociological Review 27(5): 624-635. doi:10.1093/esr/jcq028.

Meggiolaro, S. and Ongaro, F. (2008). Repartnering after marital dissolution: Does context play a role? Demographic Research 19(57): 1913-1934. doi:10.4054/ DemRes.2008.19.57.

Murinkó, L. and Szalma, I. (2016). Fatherhood and men's second union formation: Norway, France, and Hungary, 1980-2000. In: Mortelmans, D., Matthijs, K., Alofs, E., and Segaert, B. (eds.). Changing family dynamics and demographic evolution: The family kaleidoscope: Cheltenham: Elgar: 179-213.

Mynarska, M. and Bernardi, L. (2007). Meanings and attitudes attached to cohabitation in Poland: Qualitative analyses of the slow diffusion of cohabitation among the young generation. Demographic Research 16(17): 519-554. doi:10.4054/Dem Res.2007.16.17. 
Mynarska, M. and Matysiak, A. (2010). Diffusion of cohabitation in Poland. Studia Demograficzne 157(1-2): 11-25.

Ní Bhrolcháin, M. (1992). Age difference asymmetry and a two-sex perspective. European Journal of Population 8(1): 23-45. doi:10.1007/BF01797120.

Ní Bhrolcháin, M. and Sigle-Rushton, W. (2005). Partner supply in Britain and the US: Estimates and gender contrasts. Population 60(1-2): 37-64. doi:10.2307/4148 201.

Ozawa, M.N. and Yoon, H.-S. (2002). The economic benefit of remarriage. Journal of Divorce and Remarriage 36(3-4): 21-39. doi:10.1300/J087v36n03_022.

Perelli-Harris, B. (2014). How similar are cohabiting and married parents? Second conception risks by union type in the United States and across Europe. European Journal of Population 30(4): 437-464. doi:10.1007/s10680-014-9320-2.

Perelli-Harris, B., Berrington, A., Sanchez Gassen, N., Gałęzewska, P., and Holland, J. (2017). The rise in divorce and cohabitation: Is there a link? Population Development Review 43(2): 303-329. doi:10.1111/padr.12063.

Perelli-Harris, B. and Gerber, T.P. (2011). Nonmarital childbearing in Russia: Second demographic transition or pattern of disadvantage? Demography 48(1): 317342. doi:10.1007/s13524-010-0001-4.

Perelli-Harris, B., Kreyenfeld, M., and Kubisch, K. (2010). Harmonized histories manual for the preparation of comparative fertility and union histories (Revised February 2012). Rostock: Max Planck Institute for Demographic Research (MPI Working Paper WP 2010-011).

Perelli-Harris, B., Kreyenfeld, M., Sigle-Rushton, W., Keizer, R., Lappegård, T., Jasilioniene, A., Berghammer, C., and Di Giulio, P. (2012). Changes in union status during the transition to parenthood in eleven European countries, 1970s to early 2000s. Population Studies 66(2): 167-182. doi:10.1080/00324728.2012. 673004.

Perelli-Harris, B. and Lyons-Amos, M. (2016). Partnership patterns in the United States and across Europe: The role of education and country context. Social Forces 95(1): 251-282. doi:10.1093/sf/sow054.

Perelli-Harris, B., Mynarska, M., Berrington, A., Berghammer, C., Evans, A., Isupova, O., Keizer, R., Klaerner, A., Lappegård, T., and Vignoli, D. (2014). Towards a new understanding of cohabitation: Insights from focus group research across 
Europe and Australia. Demographic Research 31(34): 1043-1078. doi:10.4054/ DemRes.2014.31.34.

Pirani, E. and Vignoli, D. (2016). Changes in the satisfaction of cohabitors relative to spouses over time. Journal of Marriage and Family 78(3): 598-609. doi:10.1111/jomf.12287.

Poortman, A.-R. (2007). The first cut is the deepest? The role of the relationship career for union formation. European Sociological Review 23(5): 585-598. doi:10.1093/esr/jem024.

Raeymaeckers, P., Dewilde, C., Snoeckx, L., and Mortelmans, D. (2008). Childcare strategies of divorced mothers in Europe: A comparative analysis. European Sociological Review 24(1): 115-131. doi:10.1093/esr/jcm040.

Raley, R.K. and Bumpass, L.L. (2003). The topography of the divorce plateau: Levels and trends in union stability in the United States after 1980. Demographic Research 8(8): 245-260. doi:10.4054/DemRes.2003.8.8.

Rault, W. and Régnier-Loilier, A. (2015). First cohabiting relationships: Recent trends in France. Paris: Institut National d'Études Démographiques (Population and Sociétés No. 521).

Regnier-Loilier, A., Beaujouan, É., and Villeneuve-Gokalp, C. (2009). Neither single, nor in a couple. A study of living apart together in France. Demographic Research 21(4): 75-108. doi:10.4054/DemRes.2009.21.4.

Régnier-Loilier, A. and Prioux, F. (2015). Family behaviours and religious practice in France. In: Régnier-Loilier, A. (ed.). The contemporary family in France: Partnership trajectories and domestic organization. Cham: Springer: 87-111. doi:10.1007/978-3-319-09528-8_5.

Rijken, A.J. and Liefbroer, A.C. (2012). European views of divorce among parents of young children: Understanding cross-national variation. Demographic Research 27(2): 25-52. doi:10.4054/DemRes.2012.27.2.

Sánchez Gassen, N. and Perelli-Harris, B. (2015). The increase in cohabitation and the role of union status in family policies: A comparison of 12 European countries. Journal of European Social Policy 25(4): 431-449. doi:10.1177/0958928 715594561 .

Shafer, K. and James, S.L. (2013). Gender and socioeconomic status differences in first and second marriage formation. Journal of Marriage and Family 75(3): 544564. doi:10.1111/jomf.12024. 
Skew, A., Evans, A., and Gray, E. (2009). Repartnering in the United Kingdom and Australia. Journal of Comparative Family Studies 40(4): 561-585.

Sobotka, T. and Toulemon, L. (2008). Overview Chapter 4: Changing family and partnership behaviour: Common trends and persistent diversity across Europe. Demographic Research 19(6): 85-138. doi:10.4054/DemRes.2008.19.6.

Sodermans, A.K., Matthijs, K., and Vanassche, S. (2013). Post-divorce custody arrangements and binuclear family structures of Flemish adolescents. Demographic Research 28(15): 421-432. doi:10.4054/DemRes.2013.28.15.

Soons, J.P.M. and Kalmijn, M. (2009). Is marriage more than cohabitation? Well-being differences in 30 European countries. Journal of Marriage and Family 71(5): 1141-1157. doi:10.1111/j.1741-3737.2009.00660.x.

Spijker, J.J.A. (2012). Divorce Atlas [electronic resource]. Barcelona: Centre d'Estudis Demogràfics and Universitat Autònoma de Barcelona. https://divorceatlas. wordpress.com.

Spruijt, E. and Duindam, V. (2009). Joint physical custody in the Netherlands and the well-being of children. Journal of Divorce and Remarriage 51(1). doi:10.1080/ 10502550903423362 .

Stewart, S.D. (2005). Boundary ambiguity in stepfamilies. Journal of Family Issues 26(7): 1002-1029. doi:10.1177/0192513X04273591.

Stewart, S.D., Manning, W.D., and Smock, P.J. (2003). Union formation among men in the US: Does having prior children matter? Journal of Marriage and Family 65(1): 90-104. doi:10.1111/j.1741-3737.2003.00090.x.

Surkyn, J. and Lesthaeghe, R. (2004). Value orientations and the second demographic transition in Northern, Western, and Southern Europe: An update. Demographic Research S3(3): 45-86. doi:10.4054/DemRes.2004.S3.3.

Sweeney, M.M. (1997). Remarriage of women and men after divorce: The role of socioeconomic prospects. Journal of Family Issues 18(5): 479-502. doi:10.1177/ 019251397018005002.

Sweeney, M.M. (2002). Remarriage and the nature of divorce: Does it matter which spouse chose to leave? Journal of Family Issues 23(3): 410-440. doi:10.1177/01 $92513 \times 02023003005$.

Syltevik, L.J. (2010). Sense and sensibility: Cohabitation in 'cohabitation land.' The Sociological Review 58(3): 444-462. doi:10.1111/j.1467-954X.2010.01932.x. 
Teitler, J.O., Reichman, N.E., and Koball, H. (2006). Contemporaneous versus retrospective reports of cohabitation in the Fragile Families Survey. Journal of Marriage and Family 68(2): 469-477. doi:10.1111/j.1741-3737.2006.00265.x.

Theunis, L., Pasteels, I., and Van Bavel, J. (2015). Educational assortative mating after divorce: Persistence or divergence from first marriages? Zeitschrift für Familienforschung 27: 183-202.

Thomson, E., Lappegård, T., Carlson, M., Evans, A., and Gray, E. (2014). Childbearing across partnerships in Australia, the United States, Norway, and Sweden. Demography 51(2): 485-508. doi:10.1007/s13524-013-0273-6.

Uunk, W. (2004). The economic consequences of divorce for women in the European Union: The impact of welfare state arrangements. European Journal of Population 20(3): 251-285. doi:10.1007/s10680-004-1694-0.

van Damme, M., Kalmijn, M., and Uunk, W. (2009). The employment of separated women in Europe: Individual and institutional determinants. European Sociological Review 25(2): 183-197. doi:10.1093/esr/jen042.

Vanassche, S., Corijn, M., Matthijs, K., and Swicegood, G. (2015). Repartnering and childbearing after divorce: Differences according to parental status and custodial arrangements. Population Research and Policy Review 34(5): 761-784. doi:10.1007/s11113-015-9366-9.

Vespa, J. (2014). Historical trends in the marital intentions of one-time and serial cohabitors. Journal of Marriage and Family 76(1): 207-217. doi:10.1111/ jomf.12083.

Wu, Z. (1994). Remarriage in Canada: A social exchange perspective. Journal of Divorce and Remarriage 21(3-4): 191-224. doi:10.1300/J087v21n03_10.

Wu, Z. and Balakrishnan, T.R. (1994). Cohabitation after marital disruption in Canada. Journal of Marriage and Family 56(3): 723-734. doi:10.2307/352881.

Wu, Z. and Schimmele, C.M. (2005). Repartnering after first union disruption. Journal of Marriage and Family 67(1): 27-36. doi:10.1111/j.0022-2445.2005.00003.x. 
Gatęzewska, Perelli-Harris \& Berrington: Cross-national differences in women's repartnering behaviour 